UDK: 94(496.02)

$81^{\prime} 38$

929 Porfirogent, K.

Izvorni znanstveni članak

Primljen 21. XI. 2017.

Teuta Serreqi Jurić

Odjel za klasičnu filologiju Sveučilišta u Zadru

tserreqi@unizd.hr

\title{
STILSKE RAZINE U DJELIMA KONSTANTINA PORFIROGENETA
}

\section{Sažetak}

Pitanje autorstva književnoga korpusa sačuvana pod imenom bizantskoga cara Konstantina VII. Porfirogeneta (913. - 959.) zaokuplja proučavatelje carevih spisa više od jednoga stoljeća. Sumnje u carevo autorstvo ponajviše proizlaze iz različitih stilskih razina njegovih spisa, što je u recentnijim istraživanjima dovelo do toga da se Porfirogenetu osporavalo autorstvo većine djela. U radu se razmatraju stilske osobitosti onih dijelova Corpusa Constantineuma u kojima je, po mišljenju relevantnih stručnjaka, Porfirogenet imao vlastiti stvaralački udio. Dobiveni rezultati pokazuju da je Konstantin pisao u otprilike šest različitih stilskih razina te da su pojavu različitih stilskih izričaja uvjetovale književna vrsta, tematika građe kao i okolnost komu su djela bila adresirana. Zajedničke stilske osobitosti koje su prisutne u razmatranim dijelovima carevih spisa idu u prilog tomu da bi u ovome slučaju mogla biti riječ o istome autoru koji je varirao svoj stil pisanja.

Ključne riječi: Konstantin VII. Porfirogenet; stilske figure i tropi; stilske razine; autorstvo 


\section{Uvod $^{1}$}

Kada govorimo o korpusu koji književna tradicija pripisuje bizantskomu caru Konstantinu VII. Porfirogenetu (913. - 959.), ono što i nakon više od jednoga stoljeća istraživanja ostaje predmetom prijepora u suvremenim znanstvenim krugovima, pitanje je autorstva Konstantinovih spisa. Mišljenja oko toga što je sam car napisao ostala su još uvijek neusklađena, a rasvijetliti to pitanje ponekad nam se čini gotovo nemogućim jer je poznato kako je Porfirogenet oko sebe imao niz učenih ljudi koji su mu asistirali u književno-znanstvenome radu, ${ }^{2}$ a i sami naslovi djela, iz kojih se teško može razaznati koliki je udio careva vlastitog rada, a koliki njegovih pomoćnika, mogli bi nas obeshrabriti u tome pokušaju. ${ }^{3}$ Pridodamo li tomu i problem različitih stilskih razina, koji je

$1 \quad$ Ovaj je rad u skraćenome obliku izložen na međunarodnome znanstvenom skupu Natales grate numeras?, Zadar, 7. i 8. travnja 2017. Dijelovi ovoga rada temelje se na prerađenim i dopunjenim poglavljima doktorske disertacije Teute Serreqi Jurić (2016: 1-2, 25-30, 189-249, 278-291).

2 Imena većine Porfirogenetovih suradnika koji su boravili na carevu dvoru zasad ostaju anonimna. Poznati su nam samo Josip Genezije, koji je na Konstantinov nalog između 945. i

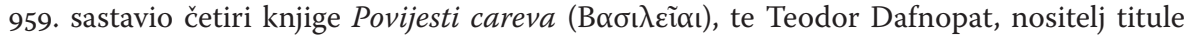
magistra i obnašatelj drugih visokih dužnosti za vladavine Romana I., Konstantina VII. i Romana II., kojemu se pripisuje drugi dio šeste knjige kronike Theoph. Cont. i koji je možda mogao sastaviti govor De imag. Edessena te govor održan prigodom prijenosa relikvija sv. Grgura iz Nazijanza iz Kapadokije u Konstantinopol.

3 Ilustracije radi, navest ćemo neke od njih. Naslov Vita Bas. glasi: „Povijesno razlaganje života i djela slavnog cara Bazilija, koje je njegov unuk Konstantin, u Bogu car Rimljana, marljivo skupivši iz različitih izlaganja priložio onomu koji piše." (Vita Bas., tit. 1-6, ed.

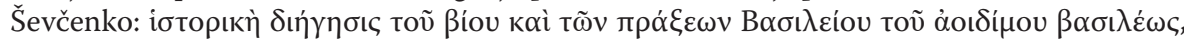

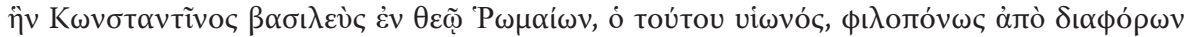

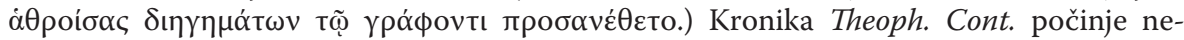
potpuno čitljivim naslovom „Ljetopis napisan po naredbi Konstantina, kristoljubivog i u grimizu rođenoga gospodara, sina Leona, premudroga gospodina i vladara ... zapo-

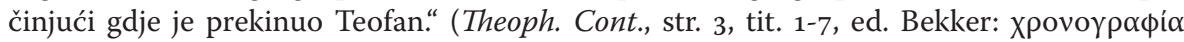

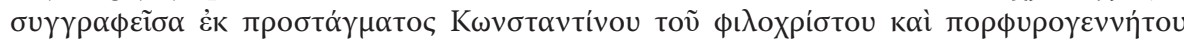

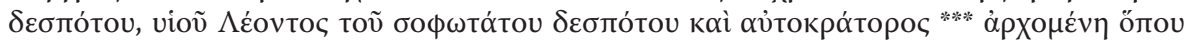

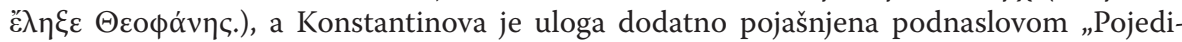
načno je osnove o njima marljivo sabrao isti car Konstanin i pregledno izložio." (Theoph.

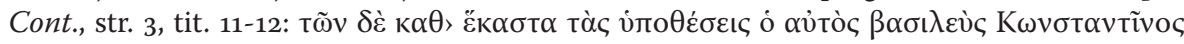

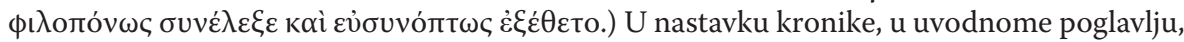
znakovita je rečenica koja govori o carevu pisanju rukom njegova pomoćnika: „Pripovijedaš sam, uzevši jedino našu ruku sebi na pomoć, što su proživjeli oni prije tebe." (Theoph.

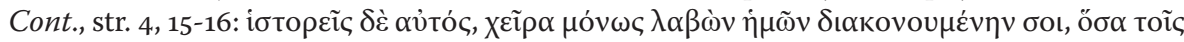


još davno uočen, nije neobično da djela tradirana kao Porfirogenetova i dalje izazivaju nedoumicu oko toga tko ih je uistinu napisao. ${ }^{4}$

Gledajući povijest proučavanja Corpusa Constantineuma, možemo izdvojiti čitav niz dragocjenih radova u kojima su iznesene bitne spoznaje na područjima datacije i autorstva Konstantinovih spisa. ${ }^{5} \mathrm{~S}$ druge strane, istraživači su se osjetno manje bavili problematikom nejednakih stilskih razina. Pritom neizostavno treba spomenuti Gyulu Moravcsika (1939), koji je prvi s jezičnoga aspekta dublje proučio Konstantinov literarni opus i time dao ne samo vrijedan uvid u njegove jezične osobitosti nego i stvorio čvrsti temelj za proučavanje njegovih stilskih obilježja, ${ }^{6}$ te Luigia Tartagliu (1982), koji u kraćim crtama uspoređuje stil De adm. imp., De cerim. i Vita Bas., analizirajući njihova odabrana sintaktička i leksička obilježja kao i uporabu nekih stilskih figura i tropa. Jedini koji je dublje zašao u ovu problematiku bio je Ihor Ševčenko (1992: 184 i bilj. 44), primijetivši kako je car, ako je autentično sve što mu se pripisuje,

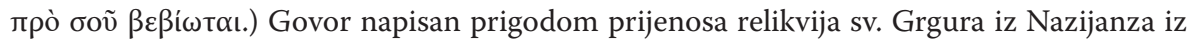
Kapadokije u Konstantinopol sadrži sljedeći naslov: „Poslanica kao od cara Konstantina Porfirogeneta na brzu ruku sastavljena i odaslana velikom Gregoriju Teologu, kad bijaše

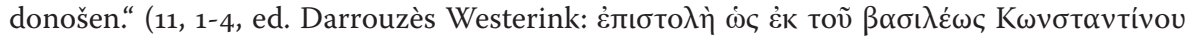

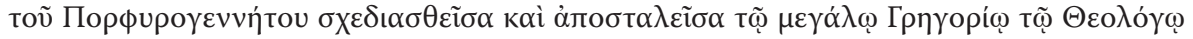

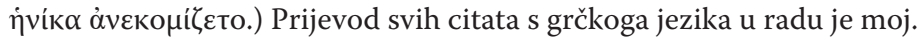

4 Razmatrajući jezične osobitosti Vita Bas., De adm. imp. i De cerim., prvu sumnju u autorstvo carevih spisa izrazio je Tycho Mommsen (1895: 449, bilj. 190 i 522-523, bilj. 41). Uočivši da upotreba prijedloga u De adm. imp. i De cerim. obiluje barbarizmima, dok je u Vita Bas. pravilna, Mommsen se s pravom zapitao jesu li ova djela proizišla iz pera istoga autora.

5 Ovdje izdvajamo samo neke: A. Rambaud (1870: 51-174), K. Krumbacher (1897: 252-264, 347-349), J. B. Bury (1907), J. B. Bury (1908), G. Ostrogorsky (1953), I. Ševčenko (1978), H. Ahrweiler (1981), Gy. Moravcsik (1983: 356-390, 540-544), P. Lemerle (1986: 310-343), a u novije vrijeme J. Signes Codoñer (1989), J. Haldon (1990: 45-68), I. Ševčenko (1992), E. Anagnostakis (1999), P. Varona (2010).

6 Uzevši u obzir careva četiri najveća prozna djela te govorničke spise, Moravcsik (1939: 515516) je uočio kako su govori napisani arhaizirajućim grčkim jezikom i visokim stilom bizantske retorike. Njima bi od proznih djela najbliži bili Vita Bas. i De them., čiji je jezik ipak manje izvještačen, no dosljedni su pravilima antičke gramatike te u njima nema vulgarizama. $S$ druge strane, od prethodno nabrojanih djela bitno odudaraju De adm. imp. i De cerim., koji su većim dijelom napisani govornim jezikom svojega vremena i prepuni vulgarizama. 
pisao u bar pet različitih stilova. ${ }^{7}$ No, za razliku od svojih prethodnika, ${ }^{8}$ Ševčenko prilikom razmatranja stilske raznolikosti Porfirogenetovih spisa ide u suprotnu krajnost, osporavajući caru autorstvo većine djela. ${ }^{9}$ Takvo konfuzno stanje glede pripisivanja i negiranja autorstva caru, kao i nedostatak iscrpnijih istraživanja i detaljnijih studija o stilskim obilježjima Konstantinovih spisa, svakako su poticajno ozračje da se careva djela dublje prouče sa stilističkoga aspekta ne bi li iz toga izronila spoznaja o tome je li uopće moguće da je isti autor mogao pisati toliko različitim stilovima. Stoga ćemo u ovome istraživanju, uzimajući u obzir Ševčenkove spoznaje, no ne isključivo i nužno, na temelju stilskih osobitosti spisa iz Konstantinova opusa, u čijem je nastanku car osobno

7 Od carevih djela koja su pisana različitim stilovima Ševčenko kao primjer navodi pisma razmijenjena s Teodorom iz Kizika, Vita Bas. i govor De imag. Edessena, uvodno poglavlje De cerim., dijelove De adm. imp. (uvodno poglavlje, pogl. 1, 4-24, pogl. 13, 12-20o), dijelove De them. (uvodno poglavlje i ostali dijelovi) te vojne govore. Pri traženju stilskih osobitosti Ševčenko (1992: 185, bilj. 46, 187, bilj. 49) je ponajviše usmjeren na zajedničke leksičke i frazeološke paralele, ne dajući pritom jasnije tumačenje koja bi careva djela pripadala višoj razini stilskoga izričaja, a koja nižoj. Osim Moravcsika, Tartaglie i Ševčenka, stilskih se osobitosti nekih Porfirogenetovih djela dotiču i radovi koje navodimo u nastavku. O jezičnim i stilskim značajkama dalmatinskih poglavlja De adm. imp., koje bi mogle ukazivati na posebna pisca, vidi M. Lončar (2002a: 102-105) i M. Lončar (2002b). Sažet prikaz najvažnijih jezičnih, sintaktičkih i stilskih obilježja Vita Bas. nudi index graecitatis Ševčenkova izdanja (2011: 367-383). Iscrpan pregled sintaktičkih, leksičkih i stilskih osobitosti Vita Bas. i De them. donosi Serreqi Jurić (2016: 116-341).

8 Većina stručnjaka ne dovodi pod sumnju Porfirogenetovo autorstvo, pripisujući ga što caru osobno, što suradnji s pomoćnicima (A. Rambaud, F. Hirsch, T. Mommsen, K. Krumbacher, J. B. Bury, Gy. Moravcsik, G. Ostrogorsky, P. Lemerle, H. Ahrweiler, A. Toynbee, H. Hunger, L. Tartaglia, J. Signes Codoñer, J. Haldon, E. Anagnostakis i drugi).

9 Ševčenko (1992: 184-185 i bilj. 46) smatra da autor Vita Bas. nije Porfirogenet, već ista osoba koja je sastavila govor De imag. Edessena, pri čemu kao dokaz podastire oko dvadeset i pet leksičkih i frazeoloških paralela koje je uočio u obama djelima. Što se tiče De them. i De cerim., samo bi uvodna poglavlja bila careva. Od ostalih govora sačuvanih pod carevim imenom vojni govori pokazuju samo nekoliko leksičkih sličnosti i nijednu stilsku u odnosu na ostale dijelove Konstantinovih spisa, dok je za govor održan prigodom prijenosa relikvija sv. Ivana Zlatoustoga još u prethodnim istraživanjima potvrđena sumnja u Porfirogenetovo autorstvo (Ševčenko, 1992: 187, bilj.49). Kada je riječ o govoru sastavljenom prigodom prijenosa relikvija sv. Grguru iz Nazijanza iz Kapadokije u Konstantinopol, problematičan je već sami njegov naslov, koji nam ujedno onemogućuje pripisati ga Konstantinu. Ševčenko (1992: 176, 182 i bilj.40) zaključuje kako se izvornim Konstantinovim zapisima mogu smatrati samo careva pisma razmijenjena s prijateljem Teodorom te određeni dijelovi De adm. imp., odnosno uvodno poglavlje, pogl. 1, 4-24 te pogl. 13, 12-20o. 
sudjelovao, ${ }^{10}$ pokušati odgonetnuti o koliko je stilskih razina riječ te $\mathrm{u}$ okvirima tih saznanja careva djela smjestiti na hijerarhijsku ljestvicu u skladu sa stilskim značajkama koje se u njima uočavaju. Kako se problem različitih stilskih razina nužno isprepliće s pitanjem autorstva carevih djela, nastojat ćemo se približiti odgovoru i na pitanje koji su razlozi uvjetovali pojavu različitih stilskih izričaja i jesu li razlike tolike da bi morale neizostavno ukazivati na različite autore ili bi, pak, isti autor mogao varirati svoj stil pisanja u nadi da će time na svoje pravo mjesto biti posložena barem jedna od kockica u mozaiku zagonetke oko Porfirogenetova autorstva.

\section{Korpus istraživanja}

Proučavajući Porfirogenetovu literarnu ulogu, znameniti je njemački bizantolog Karl Krumbacher (1897: 252-253) još krajem 19. stoljeća istaknuo kako se ona kreće u rasponu od poticanja pozitivna okruženja za književni rad sve do ich-forme, no teško je povući granicu među tim stupnjevima te odrediti razinu careva osobnog angažmana. ${ }^{11}$ Pozamašan je broj djela povezanih $s$ Konstantinovim imenom strukturirao $u$ dvije grupe:

- djela koja je car sam napisao ili osobno sudjelovao u njihovu nastanku ${ }^{12}$

10 O korpusu na kojem je provedeno istraživanje vidi niže u nastavku rada.

${ }_{11}$ Pregledi Porfirogenetovih djela u: K. Krumbacher (1897: 252-264, 347-349), A. Toynbee (1973: 575-598), R. Katičić (1977: 332-333), H. Hunger (1978: I/339-343, 360-367, 532-533; II/96, 265-266, 273, 305-306, 329, 334-335, 447, 455-457), Gy. Moravcsik (1983: 356-390, 540544), P. Lemerle (1986: 310-343).

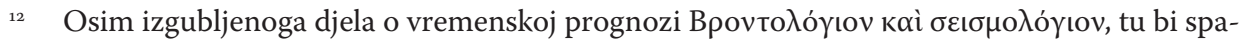

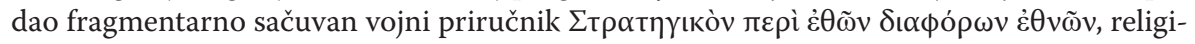

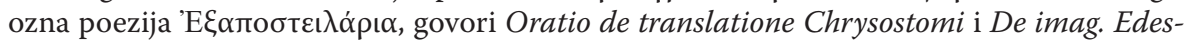
sena, govor održan prigodom prijenosa relikvija sv. Grgura iz Nazijanza, dva svečana vojna govora održana bizantskoj vojsci krajem careve vladavine te četiri prozna djela, De them., Vita Bas., De adm. imp. i De cerim. Appendix II prvoj knjizi De cerim. u Bonnskome izdanju koji je priredio Johann J. Reiske (1829), prepoznat je kasnije kao zasebno carevo djelo nazvano De expeditione. 
- zbirke tekstova odnosno izvadaka iz starijih klasičnih ili bizantskih grčkih autora te spisi enciklopedijske naravi sastavljeni na carev nalog 13

Ograničeni tim saznanjima u ovome smo istraživanju nužno upućeni na onaj dio Konstantinove književne ostavštine u čijem je nastanku car imao vlastiti udio; osvrnut ćemo se, stoga, na ona mjesta u carevim spisima koja su pisana u prvome licu ili gdje se car obraća svojemu sinu i koja se, kao što je to uočeno u prethodnim komentarima, s velikim pravom mogu smatrati Konstantinovima (Moravcsik, 1939: 518; Ševčenko, 1992: 176, 182 i bilj. 40). Pored carevih pisama razmijenjenih s prijateljem Teodorom iz Kizika to su svakako i uvodna poglavlja u De cerim. i De them. te uvodno poglavlje, pogl. 1, 4-24 i pogl. 13, 12-20o u De adm. imp. ${ }^{14}$ razlog zbog kojega su, osim spomenutih mjesta, izostavljeni ostali dijelovi tih triju spisa leži u tome što su ta djela kompilacijskoga karaktera i u svojoj su glavnini sastavljena iz starijih izvora. ${ }^{15} \mathrm{Na}$ starijim se vrelima temelji i veći dio vojnoga priručnika De expeditione, dok se Konstantinu pripisuju prolog i još jedno mjesto u spisu adresirano Romanu (C, 8-53 i 607-617, ed. Haldon), koji će također biti analizirani. Promotrit ćemo u cjelini i biografiju Porfirogenetova djeda Bazilija Vita Bas. gdje se prvo lice, osim u uvodnome poglavlju koje se također

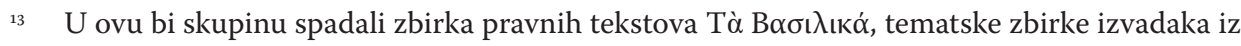

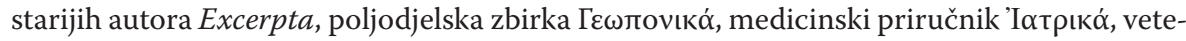

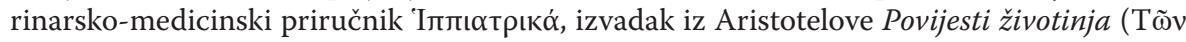

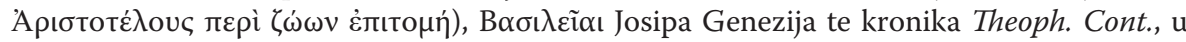
sklopu koje se kao peta knjiga nalazi Vita Bas., životopis Porfirogenetova djeda Bazilija.

14 Pored spomenutih dijelova iz De adm. imp. koje ponajviše smatra Konstantinovima, Ševčenko (1992: 188, bilj. 51) među mjestima u ostatku istoimenoga spisa, gdje je upotrijebljeno prvo lice ili se car obraća sinu, navodi i poglavlja 43/2, 45/68, 75, 102, 105 i 46/167.

15 Usp. apparatus fontium i Fontes et testimonia u Pertusijevu izdanju De them. (1952: 203205) te Index of Sources and Parallel Passages u izdanju De adm. imp. koje su priredili Moravcsik i Jenkins (1967: 337-341). Vogtovo izdanje De cerim. (1967) ne nudi apparatus fontium ni index locorum, no Moravcsik (1983: 381) nam donosi podatak da je dijelove spisa koji se odnose na sina Romana i uvodno poglavlje napisao sam car, dok su ostatak djela sastavili carevi suradnici, pri čemu je nepoznati redaktor djelo dopunio Porfirogenetovim materijalima i kasnijim tekstovima koji potječu iz vremena cara Nikefora II. Foke, a neka su poglavlja preuzeta iz izgubljenog djela Petra Patricija (6. st.), iz Ekthesisa Epifanija s Cipra (4. st.). te iz Filotejeva Kletorologiona (9. st.). 
pripisuje samomu caru, javlja na samo još jednome mjestu, ${ }^{16}$ svečane vojne govore održane krajem Porfirogenetove vladavine te na carev nalog sastavljen govor De imag. Edessena, koji je održan prigodom obilježavanja dana povratka čudotvorne Kristove slike iz Edese u Konstantinopol 944. godine (Moravcsik, 1983: 361; Lemerle, 1986: 314). Pored tih dvaju govora književna nam tradicija pod Konstantinovim imenom donosi još dva - Oratio de translatione Chrysostomi, održana najvjerojatnije povodom petstote obljetnice prijenosa relikvija sv. Ivana Zlatoustoga (Moravcsik, 1983: 361), te govor napisan prigodom prijenosa relikvija sv. Grgura iz Nazijanza iz Kapadokije u Konstantinopol, no situacija je oko autorstva tu također zamršena. Već nas sami naslov potonjega govora obeshrabruje i sprječava pripisati ga samomu caru, ${ }^{17}$ dok su, što se tiče prvoga, znanstvenici u prethodnim istraživanjima također izrazili sumnju u Konstantinovo autorstvo (Lemerle, 1986: 313-314; Ševčenko, 1992: 187, bilj. 49). Upravo iz navedenoga razloga ti govori također nisu uključeni u korpus na kojem je istraživanje provedeno.

\section{Stilske razine u Konstantinovim spisima}

\section{1. Korespondencija s Teodorom iz Kizika}

Početna točka za razmatranje Porfirogenetova stila neizostavno trebaju biti njegova pisma upućena prijatelju Teodoru, biskupu grada Kizika, koja se smatraju jedinim primjerom carevih neosporno autentičnih zapisa (Ševčenko, 1992: 176). Pisma se datiraju u vrijeme vladavine Romana I. Lekapena, između 941. (napad ruskoga kneza Igora na Konstantinopol) ${ }^{18}$ i Romanova pada krajem 94.4. godine (Darrouzès, 1960: 59). U

${ }_{16} \quad$ Vita Bas., 71, 34-35 (ed. Ševčenko).

${ }_{17}$ Naslov djela glasi: „Poslanica kao od cara Konstantina Porfirogeneta na brzu ruku sastavljena i odaslana velikom Gregoriju Teologu, kad bijaše donošen." (11, 1-4, ed. Darrouzès We-

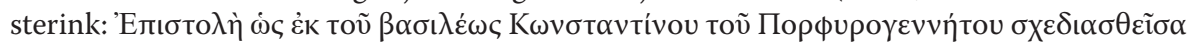

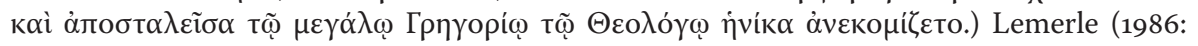
314-315) spominje mogućnost kako je govor možda mogao sastaviti Teodor Dafnopat, nositelj titule magistra i obnašatelj raznih drugih visokih dužnosti u vrijeme Romana I., Konstantina VII. i Romana II.

18 Na invaziju ruskoga kneza Igora odnosilo bi se mjesto VIII, 5, 15 (ed. Darrouzès): $\mu$ oviòc

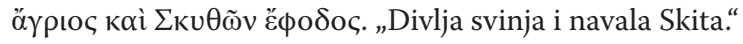


njima se sam car na više mjesta žali na nedostatke svojega stila pisanja pozivajući se na učestalu pojavu grešaka i barbarizama:

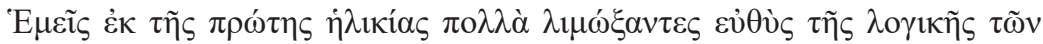

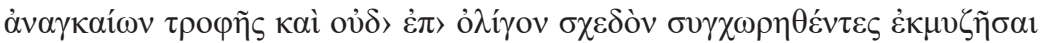

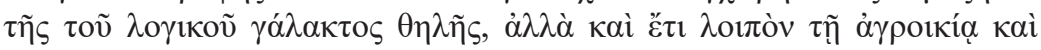

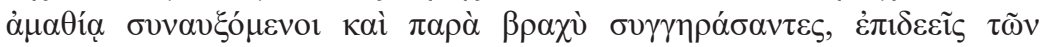

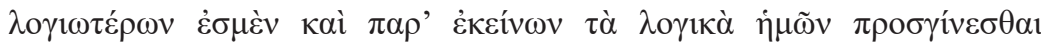

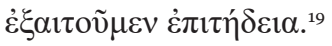

„Mi smo od najranije mladosti odmah bili veoma gladni umne hrane u glavnim stvarima, i nije nam niti blizu bilo dopušteno sisati sisu iz koje teče mlijeko znanja; nego, još ćemo i dalje rasti u nespretnosti i neukosti i, u kratko vrijeme ostarjevši, potrebiti smo učenijih ljudi i tražimo da od njih pristignu naše umne koristi."

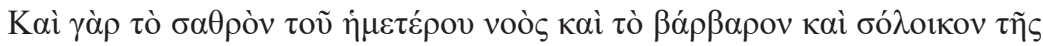

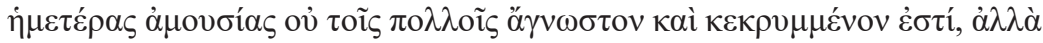

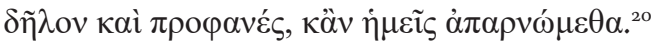

„Naime, slabost našega uma i barbarizmi i pogreške naše neukosti nisu mnogima nepoznati i skriveni, već jasni i očiti, iako mi to poričemo."

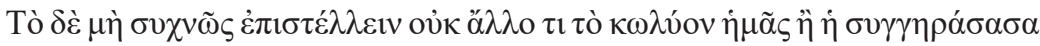

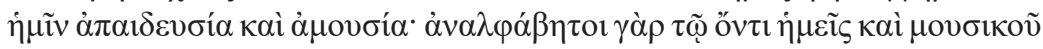

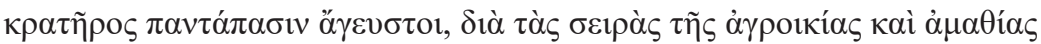

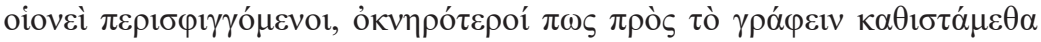

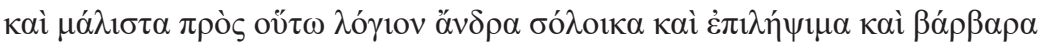

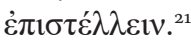

„Ono što nas sprječava često slati pisma nije ništa drugo nego neobrazovanost i neukost koja je ostarjela zajedno s nama; jer mi smo uistinu nepismeni i svakako nismo okusili naobrazbu; kao stegnuti uzicom nespretnosti i neukosti, nekako plašljivo pristupamo pisanju, a najviše slanju pogrešnih, prijekornih i barbarskih riječi tako učenom čovjeku."

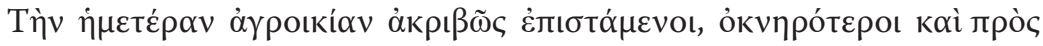

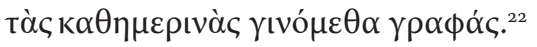

„Točno poznavajući našu nespretnost, oklijevamo pisati i današnje pismo." ${ }^{23}$

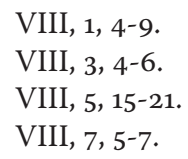

Ostala mjesta na kojima car izražava ideju o svojem niskom stilu pisanja su VIII, 1, 12-14:

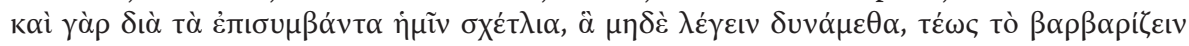


Ispričavajući se Teodoru zbog pogrešaka u pismima, Konstantin na jednome mjestu navodi razlog svoje neukosti kao i nezgrapnosti u pisanju, aludirajući na Romana I. Lekapena, uzurpatora njegova prijestolja:

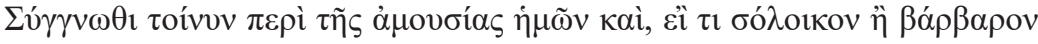

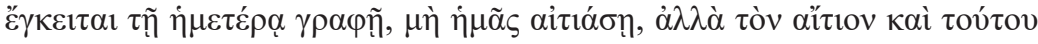

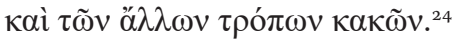

„Oprosti dakle na našoj neukosti i, ako se neka pogreška ili barbarizam nađe u našem pismu, ne okrivljuj nas, već onoga koji je zaslužan za to i za druga loša svojstva."
\end{abstract}

Međutim, unatoč Konstantinovu neprestanom isticanju svoje neukosti i manjka obrazovanja te upotrebe solecizama i barbarizama, u pismima se u carevu načinu pisanja očituje njegovo ne baš nezavidno stilsko umijeće. Ono što je već na prvi pogled lako uočiti svakako su česta leksička ponavljanja, ${ }^{25}$ no vulgarizmi su rijetki. ${ }^{26}$ Od stilskih figura prisutne su u najvećoj mjeri figure iskaza (epanalepsa, etimološka figura, hiperbat, homeoarkt, homeoteleut, izokolon s homeoteleutom ili homeoptotom, metabola, paromeoza, paronomazija, poliptot, polisindeton,

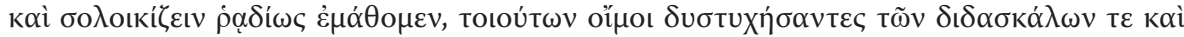
к $\alpha \theta \eta \gamma \eta \tau \tilde{\omega} v$. „I zbog proživljenih nesretnih događaja, o kojima ne možemo niti govoriti, odonda smo lako naučili govoriti barbarski i pogrešno, jer nismo imali sreće, jao meni, ima-

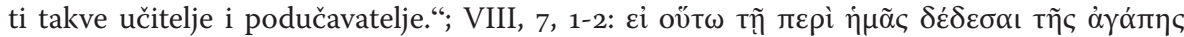

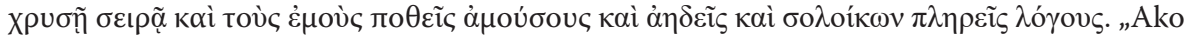
si tako vezan zlatnim lancem ljubavi prema nama i čezneš za mojim neobrazovanim i neu-

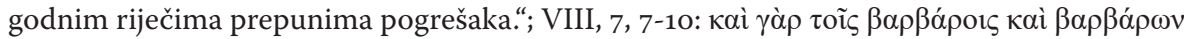

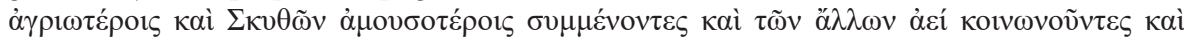

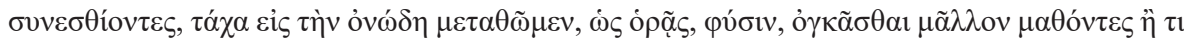

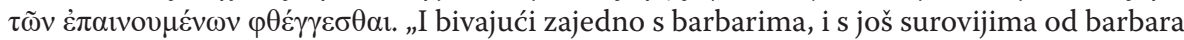
te neobrazovanijima od Skita, i u drugim stvarima stalno zajedno učestvujući te zajedno jedući, brzo smo, kao što vidiš, poprimili magareću narav, naučivši više rikati nego govoriti nešto pohvalno."

${ }^{24}$ VIII, 1, 33-35.

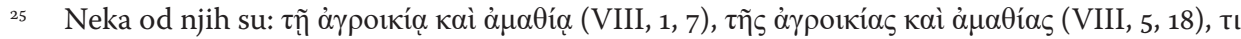

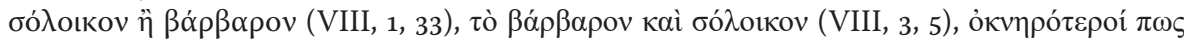

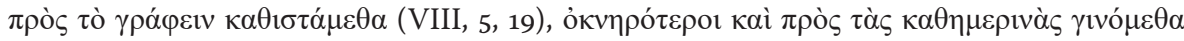

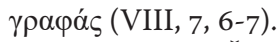

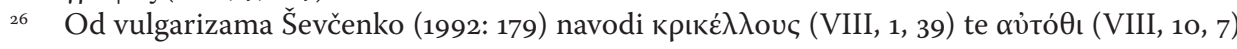
u značenju „ondje“. 
sinonimija, zeugma), ${ }^{27}$ nešto manje figure mišljenja (adinaton, antiteza, egzetazam, epanortoza, hijazam, obsekracija, oksimoron, personifikacija, poredba $)^{28}$ te od tropa perifraza i brojni primjeri metafore. ${ }^{29} \mathrm{U}$ šest od ukupno osam Konstantinovih pisama citirano je ili parafrazirano Sveto pismo. $^{30}$ Stoga, ako careve uporne isprike zbog nespretna stila pisanja, koje su, prema njegovim riječima, posljedica njegove nepismenosti zbog manjka obrazovanja u mladosti, shvatimo kao obilježje njegova osobnog stilskog izričaja, gdje se možda doista osjećao nedostojnim takvim jezikom pisati svomu vrlo učenu i obrazovanu prijatelju, ili ih stavimo u okvire uzusa ondašnjega vremena gdje je prilikom pismene komunikacije bilo poželjno i uobičajeno izražavanje poniznosti i skromnosti, sagledajući Konstantinova djela u cjelini, careva bi pisma na zamišljenoj hijerarhijskoj ljestvici zauzimala središnje mjesto po svojim stilskim

${ }_{27}$ Upotreba stilskih sredstava bit će potkrijepljena s po jednim primjerom za svaku stilsku

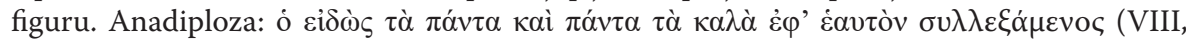

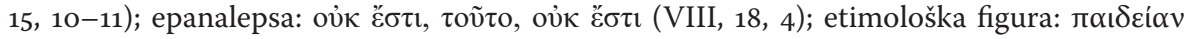

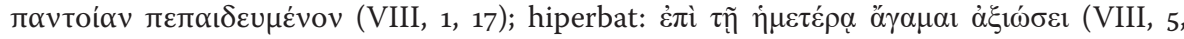

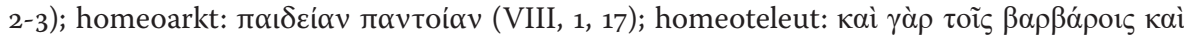

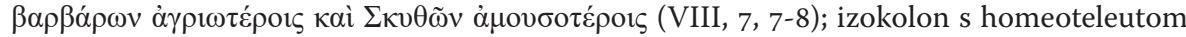

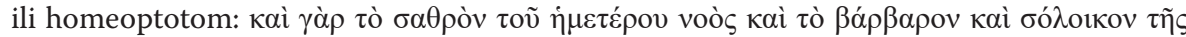

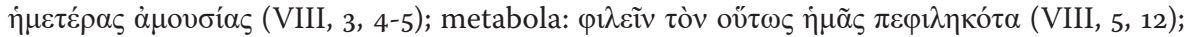

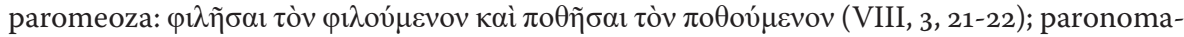

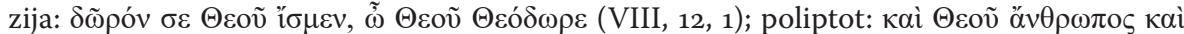

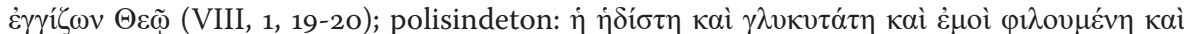

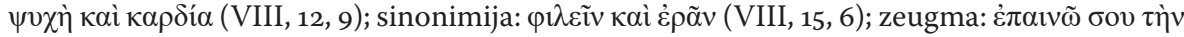

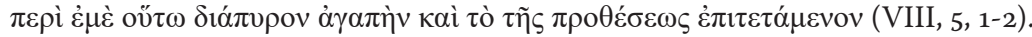

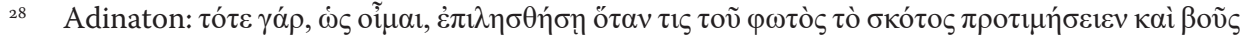

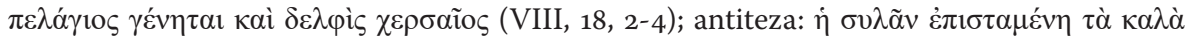

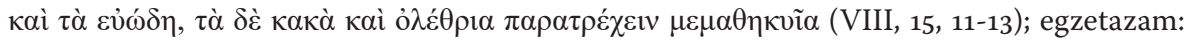

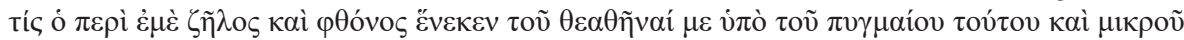

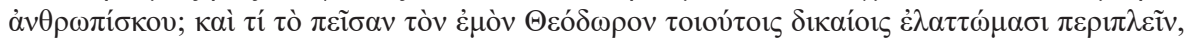

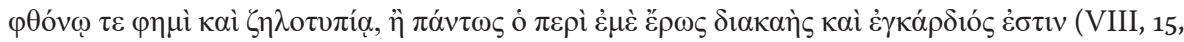

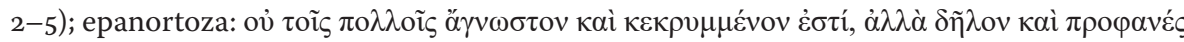

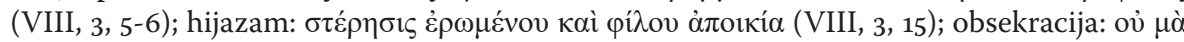

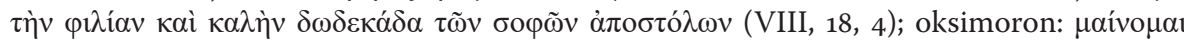

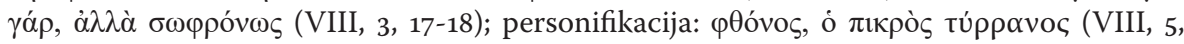

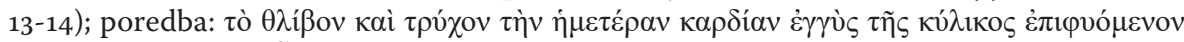

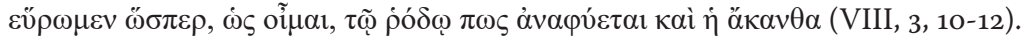

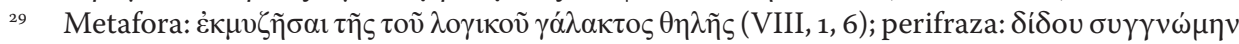
(VIII, 10, 10).

3o VIII, 1, 20; VIII, 3, 10; VIII, 5, 24; VIII, 7, 17-19; VIII, 15, 7; VIII, 18, 8. 
osobitostima. Ostale ćemo razmatrane dijelove carevih spisa, kao što ćemo vidjeti u nastavku, s obzirom na njihova stilska obilježja moći svrstati ili ispod ili iznad pisama koja je Konstanin razmijenio s Teodorom.

\section{2. Uvodna poglavlja De them., De cerim., De adm. imp. i De expeditione}

Spisi De them., De cerim. i De adm. imp. izrazito su dokumentarna karaktera i nisu bili namijenjeni široj publici, o čemu svjedoči njihova relativno siromašna rukopisna tradicija. $S$ najvećim pravom to možemo potvrditi za De adm. imp., priručnik namijenjen Konstantinovu sinu Romanu s delikatnim diplomatičnim uputama kako upravljati carstvom, čiji povjerljivi sadržaj zacijelo nije bio namijenjen objavljivanju (Moravcsik, 1983: 365; Moravcsik i Jenkins, 1967: 13-14). Osim spomenuta dokumentarnog sadržaja, svim je trima spisima zajedničko i to da se u svojoj velikoj većini temelje na starijim izvorima iz antičkih i bizantskih autora. ${ }^{31}$ Iz ovoga svakako izdvajamo njihova uvodna poglavlja te dijelove 1. i 13. poglavlja iz De adm. imp.; za ova je mjesta, koja su pisana u ich-formi i gdje se Konstantin izravno obraća sinu Romanu, uvriježeno mišljenje da ih je s vrlo velikom vjerojatnošću napisao sam car (Moravcsik, 1939: 518; Ševčenko, 1992: 176, 182 i bilj. 40). ${ }^{32}$ Uvodna bi poglavlja iz De them. i De cerim. s prevladavajućim figurama iskaza (adjunkcija, anafora, hiperbat, homeoarkt, homeoteleut, metabola, paromeoza, polisindeton,

${ }_{31} \quad$ Usp. bilj. 15.

${ }^{32}$ Usporedimo li s jezičnoga aspekta uvodna poglavlja tih triju spisa s njihovim ostalim dijelovima, uočavamo da je uvodno poglavlje De them. jezično ujednačeno s ostatkom spisa (čitav je spis pisan arhaizirajućim grčkim jezikom), dok je za uvodna poglavlja De adm. imp. i De cerim. Moravcsik (1939: 518) naglasio kako se car u njima, kao i na ostalim mjestima gdje se izravno obraća svomu sinu, služi arhaizirajućim grčkim jezikom, za razliku od ostalih dijelova spisa koji se temelje na starijim izvorima u kojima prevladava govorni grčki jezik. 


\section{sinonimija, zeugma) ${ }^{33}$ i jednom figurom mišljenja (poredba) ${ }^{34}$, uočenom u De cerim., pripadala nižoj stilskoj razini od razmatranih dijelova iz $D e$ adm. imp., koje pored većega broja figura iskaza (adjunkcija, hiperbat, homeoarkt, homeoteleut, izokolon s homeoteleutom ili homeoptotom, metabola, paromeoza, paronomazija, poliptot, polisindeton, sinonimi- ja, zeugma) ${ }^{35}$ te figura mišljenja (antiteza, epanortoza, hijazam, obse-}

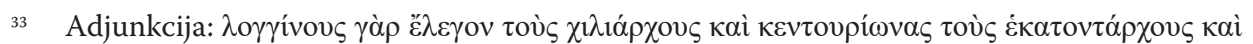

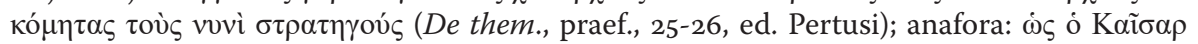

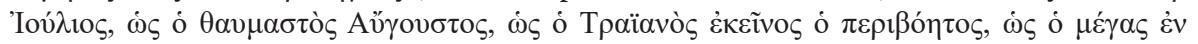

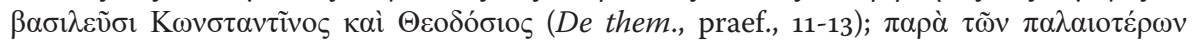

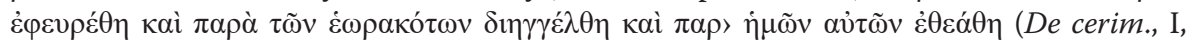

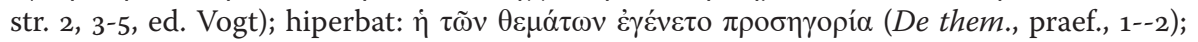

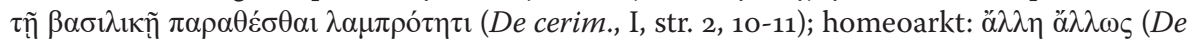

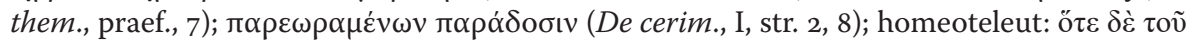

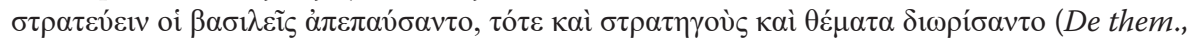

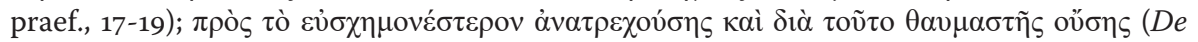

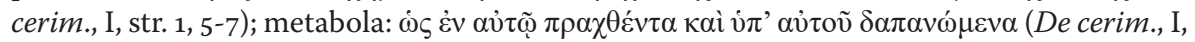

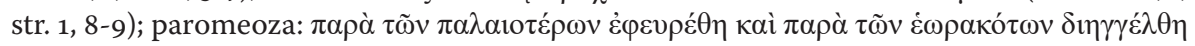

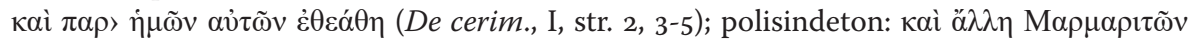

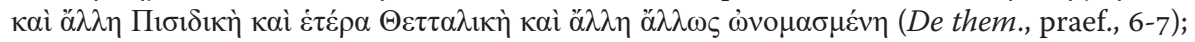

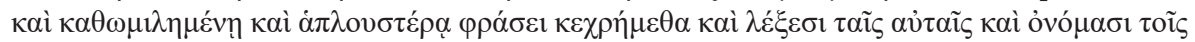

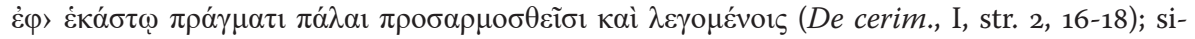

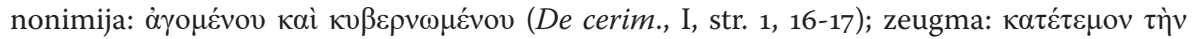

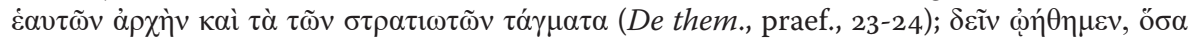

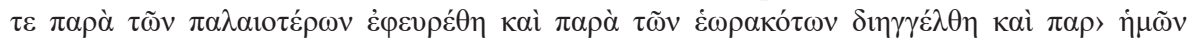
$\alpha$

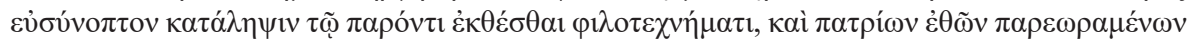

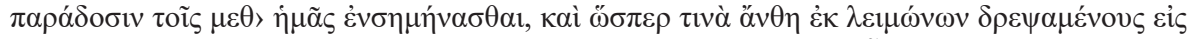

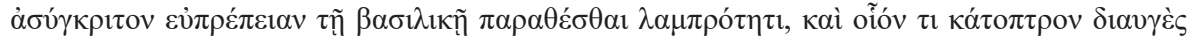

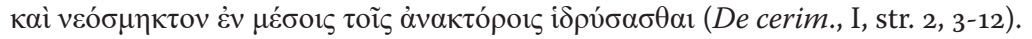

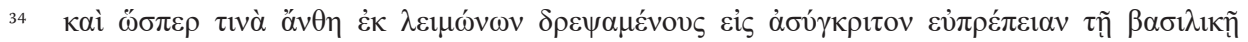
$\pi \alpha \rho \alpha \theta \dot{\varepsilon} \sigma \theta \alpha \imath$ $\lambda \alpha \mu \pi \rho \operatorname{có}_{\tau} \tau \imath$ (De cerim., I, str. 2, 9-11).

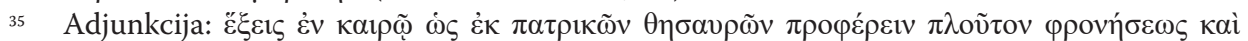

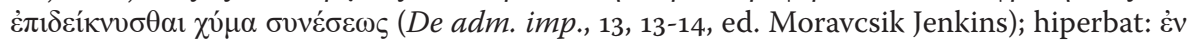

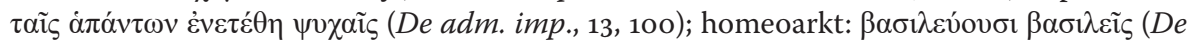

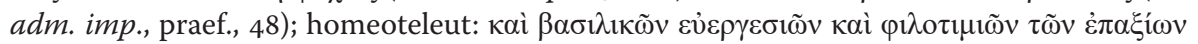

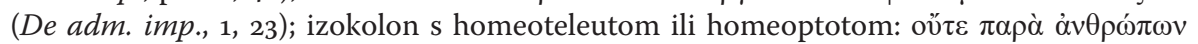

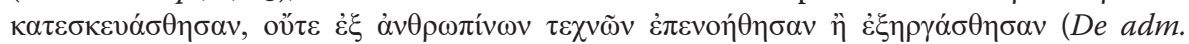

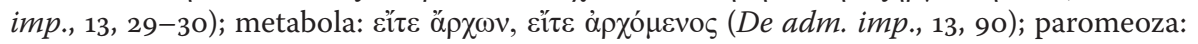

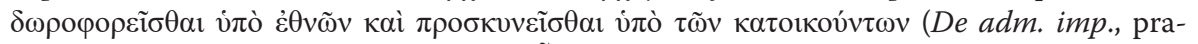

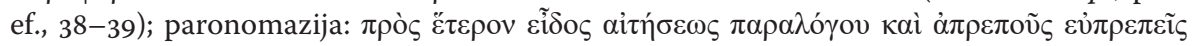

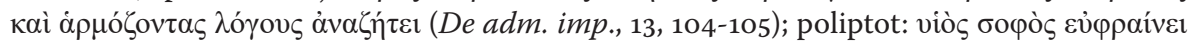

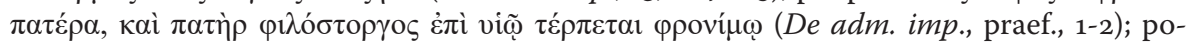

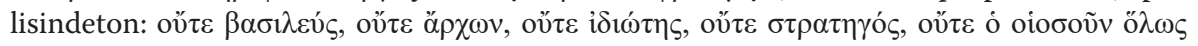


kracija, sermocinacija, poredba $)^{36}$ krasi i uporaba tropa antonomazije i perifraze kao i obilje metafore. ${ }^{37} \mathrm{~S}$ obzirom na to da je spis bio sastavljen za mladoga princa Romana, a neka saznanja govore o tome da mu je možda bio predan kao poklon za četrnaesti rođendan (Moravcsik, 1983: 365), metafora se nameće sasvim prirodnomu Konstantinovom intimnom i didaktičnom tonu kojim su obojane očeve riječi upućene sinu. Posebnomu ozračju doprinose i citati i parafraze iz Svetoga pisma, koje ne nalazimo u uvodnim poglavljima De them. i De cerim..$^{38}$ Upravo iz nabrojanih razloga dijelovi iz De adm. imp. pokazuju višu razinu stilskoga izričaja, pa bi ih hijerarhijski trebalo smjestiti svakako iznad uvodnih poglavlja iz De them. i De cerim., koja bi bila na dnu naše zamišljene ljestvice.

Sinu Romanu Konstantin je posvetio i vojni priručnik De expeditione, pri čijem se sastavljanju, kako kazuju njegove riječi u prologu, poslužio spisom magistra Leona Katakile. Konstantinovima se smatraju dva mjesta adresirana Romanu, uvodno poglavlje (8-53) i 607-617 (Haldon, 1990: 41). S obzirom na to da i u tim dijelovima nalazimo mali

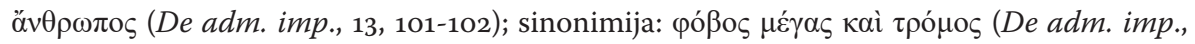

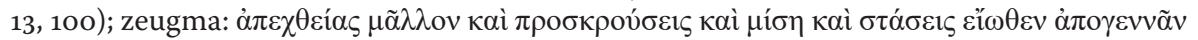
(De adm. imp., 13, 184-185).

${ }^{36}$ Antiteza: $\pi \rho$ ò

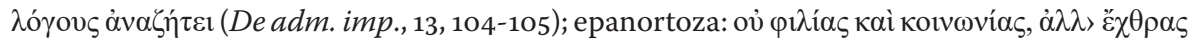

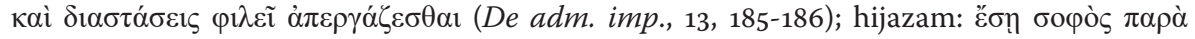

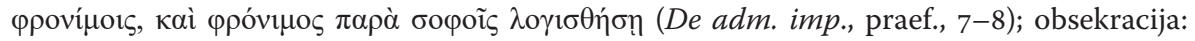

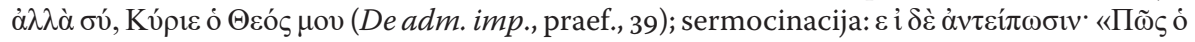

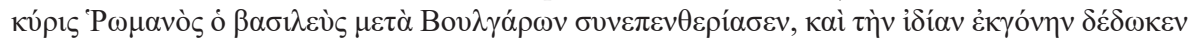

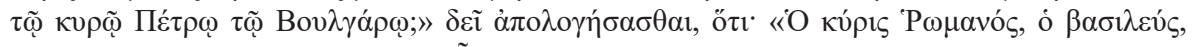

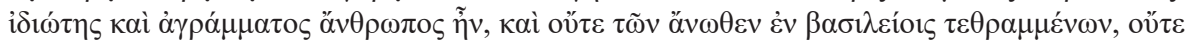

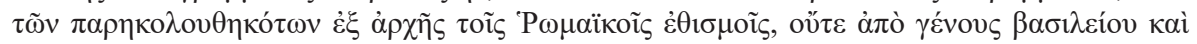

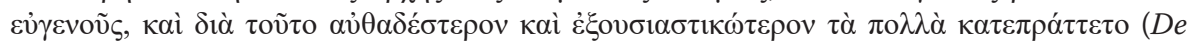

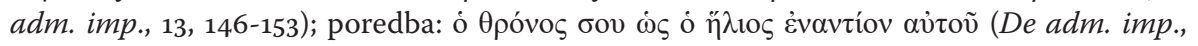
praef., 33).

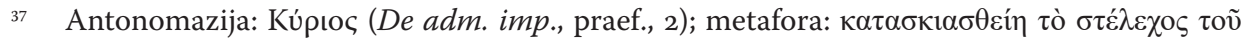

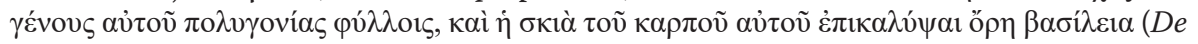

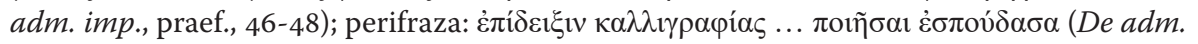
imp., 1, 10-12).

${ }_{38}$ Usp. apparatus fontium te Index of Sources and Parallel Passages u izdanju De adm. imp. koje su priredili Moravcsik i Jenkins (1967: 337-341). Osim citata i parafraza iz Svetoga pisma, koji su najbrojniji, autor je na jednome mjestu citirao i Homera (De adm. imp., 13, 104). 
broj uporabljenih stilskih ukrasa, točnije sedam figura iskaza (hiperbat, homeoarkt, homeoteleut, izokolon s homeoptotom ili homeoteleutom, metabola, polisindeton, zeugma), ${ }^{39}$ tri mišljenja (antiteza, poredba, retoričko pitanje) ${ }^{40}$ te od tropa metaforu i litotu, ${ }^{41}$ i u ovome slučaju možemo zaključiti kako je riječ o vrlo jednostavnu stilu pisanja.

\subsection{Vita Bas. i De imag. Edessena}

Pohvalni govor Vita Bas., napisan u čast Porfirogenetova djeda Bazilija, izrazito je politički obojen spis kojim je Konstantin htio svoga djeda Bazilija očistiti od krivnje za ubojstvo njegova prethodnika na prijestolju cara Mihaela III. kao i potvrditi legitimitet makedonske dinastije ustoličene s Bazilijem I. te svoju pripadnost njoj, jer je duže vrijeme postojala sumnja kako je otac Porfirogenetova oca Leona VI. bio Mihael III., a ne Bazilije (Toynbee, 1973: 582-598). Snažan propagandni karakter uvjetovao je ovdje osobitu zasićenost stilskim izražajnim sredstvima, kojom ovaj spis daleko nadmašuje ostala careva djela. Čitav je govor napisan visokim stilom bizantske retorike, pri čemu treba naglasiti da su u njemu uvodno poglavlje i ostatak djela stilski i jezično ujednačeni, za razliku od De them., De cerim. i De adm. imp. Autor Bazilijeve biografije uporabio je dvadeset figura iskaza (adjunkcija, anafora, anakolut, asindeton, epanalepsa, etimološka figura, hendiadioin, hiperbat, ${ }^{42}$

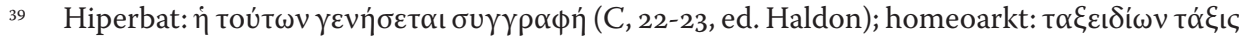

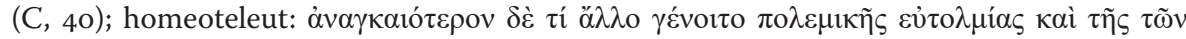

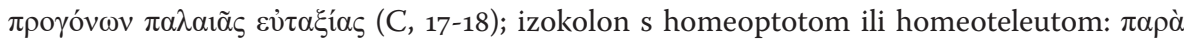

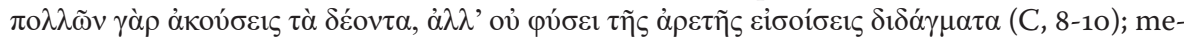

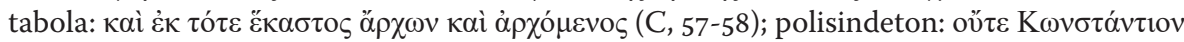

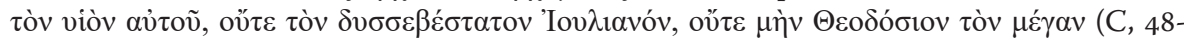

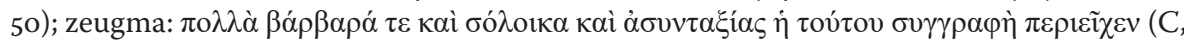
30-31).

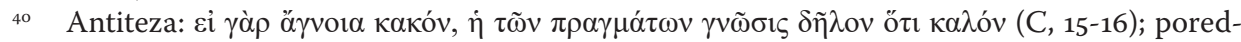

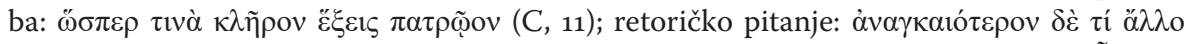

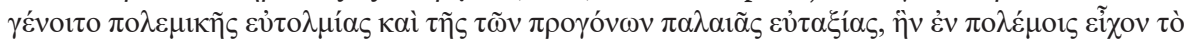

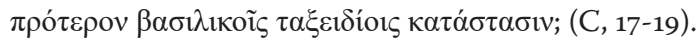

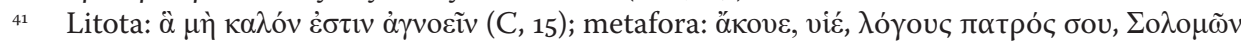

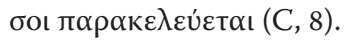

42 Osim uobičajenih oblika hiperbata, u spisu su uočeni i primjeri gdje se unakrsno isprepliću

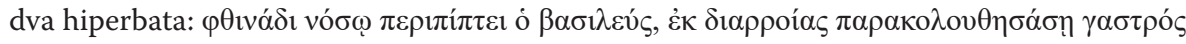


homeoarkt, homeoteleut, ${ }^{43}$ izokolon s homeoptotom ili homeoteleutom, klimaks, metabola, paromeoza, paronomazija, poliptot, polisindeton, sinonimija, tradukcija, zeugma), ${ }^{44}$ osamnaest figura mišljenja (alegorija, antapodoza, antimetabola, antiteza, apostrofa, eksklamacija, epanortoza, epifonem, gnoma, hijazam, ${ }^{45}$ hiperbola, hipotipoza, ironi-

(Vita Bas., 102, 1-2).

43 Među homeoteleutima ima i primjera gdje ekstremno podudaranje rezultira rimom:

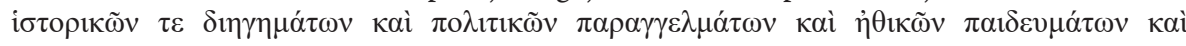

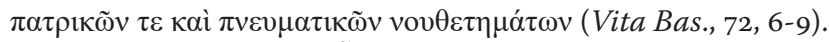

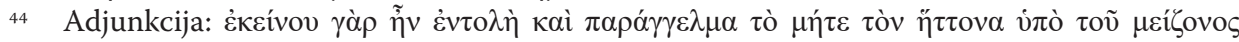

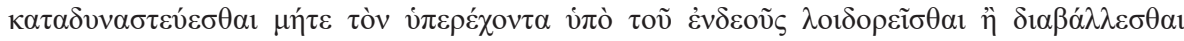

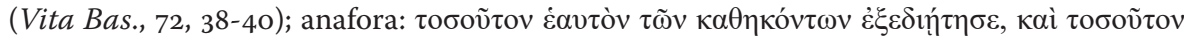

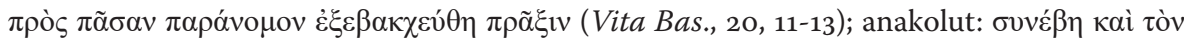

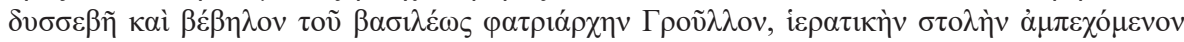

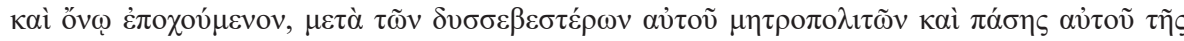

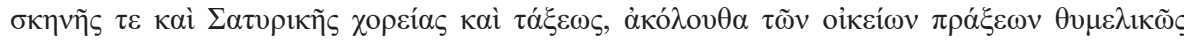

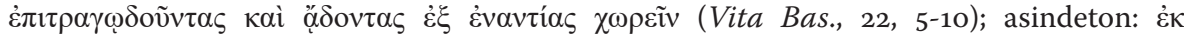

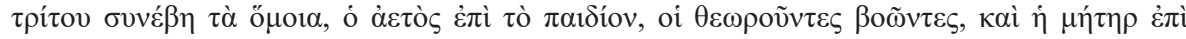

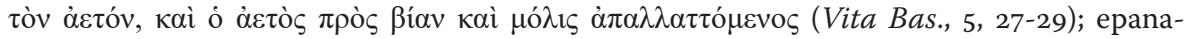

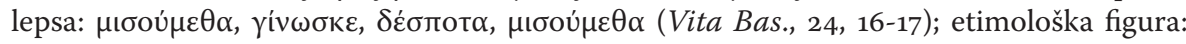

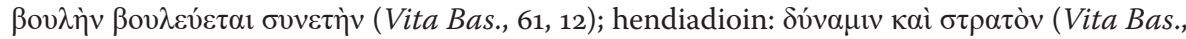

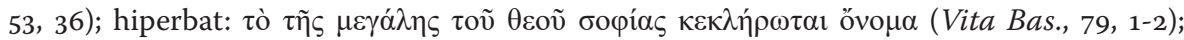
homeoarkt: $\mu \varepsilon \gamma \alpha \dot{\alpha} \lambda \eta \nu \mu \varepsilon \tau \alpha \beta 0 \lambda \eta े v$ (Vita Bas., 30, 7); homeoteleut: $\tau \alpha i \bar{\varsigma} \delta \varepsilon \xi 1 \alpha i ̄ \varsigma ~ \tau \alpha v ́ \tau \alpha 1 \varsigma ~ o ̋ \psi \varepsilon \sigma 1$,

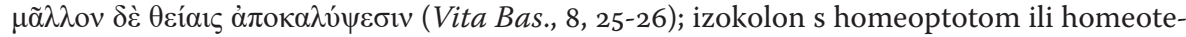

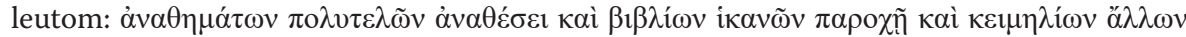

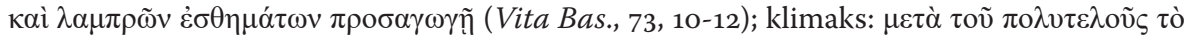

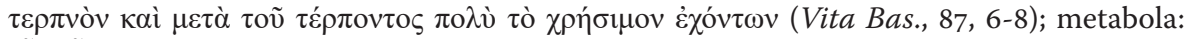

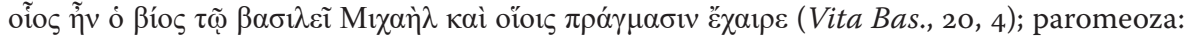

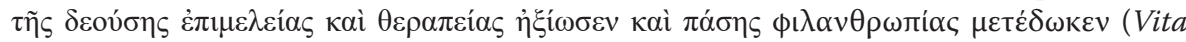

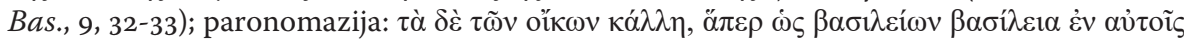

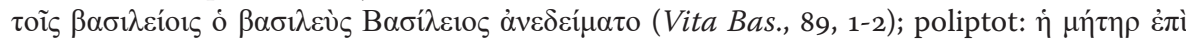

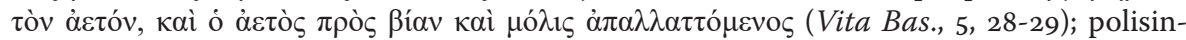

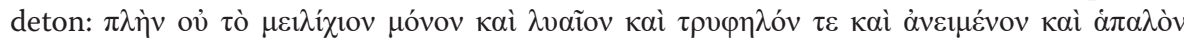

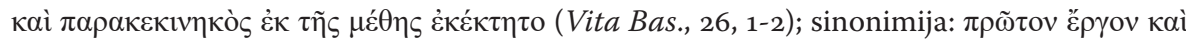

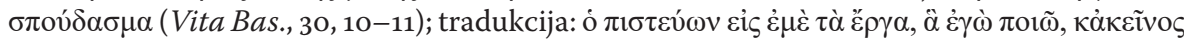

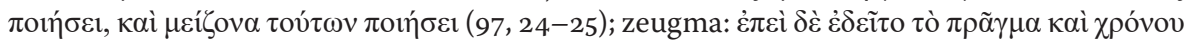

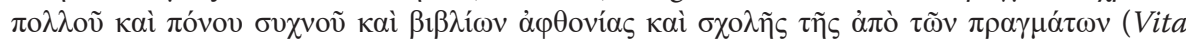
Bas., 1, 7-9).

45 Osim čistih hijazama u Vita Bas. na ponekim mjestima nalazimo i primjere gdje pisac tu stilsku figuru kombinira s hiperbatom. Takve su kombinacije uočene i u govoru De imag. Edessena te u Porfirogenetovim pismima i vojnim govorima. $\mathrm{O}$ tome vidi niže u nastavku rada te bilj. 55 i 56. 


\section{ja, paradigma, parenteza, personifikacija, poredba, retoričko pitanje $)^{46} \mathrm{i}$ pet tropa (antonomazija, litota, metafora, metonimija, perifraza). ${ }^{47}$ Osim najvećega broja uporabljenih retoričkih ukrasa, posebno je obi- lježje ovoga spisa i vrlo visok stupanj citatnosti. Njegov autor poseže za citatima kako iz klasičnih ili bizantskih grčkih pisaca tako i iz Svetoga pisma, bilo da ih preuzima od riječi do riječi ili obrađuje slobodnijim}

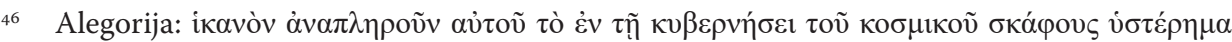

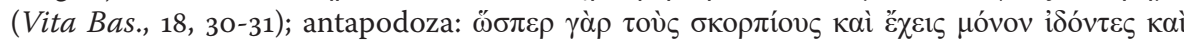

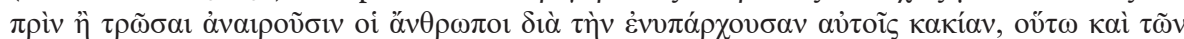

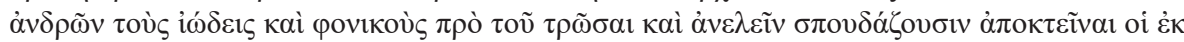

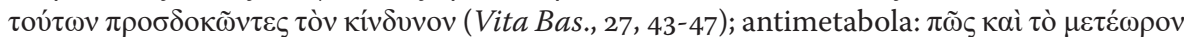

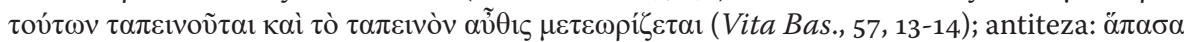

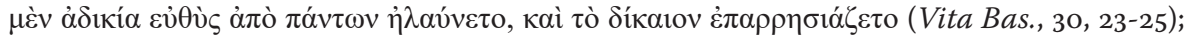

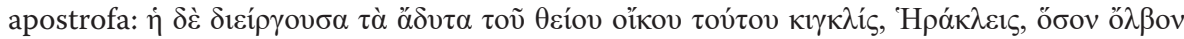

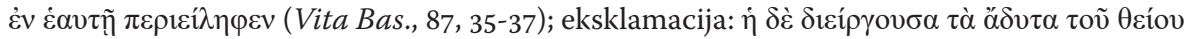

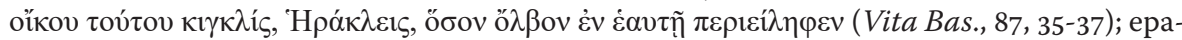

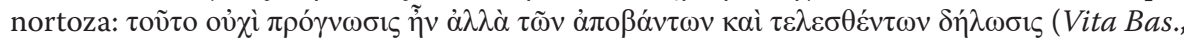

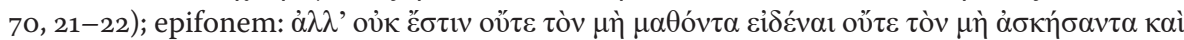

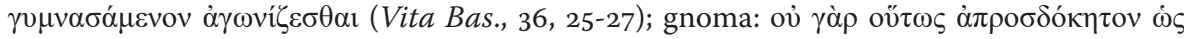
ă

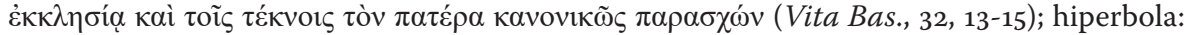

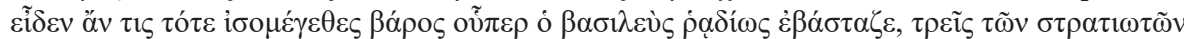

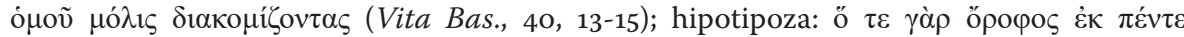

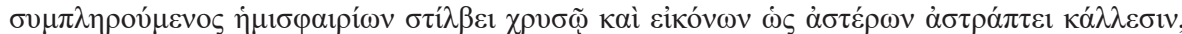

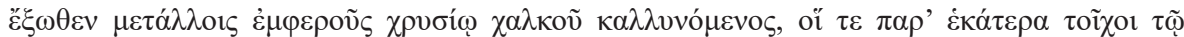

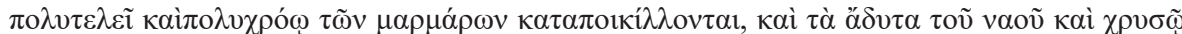

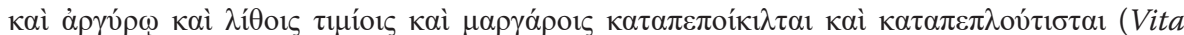

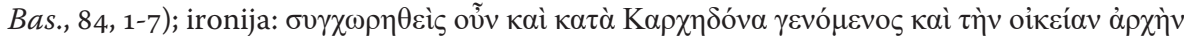

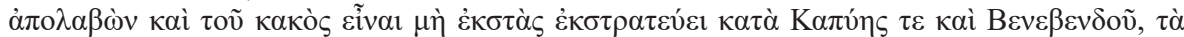

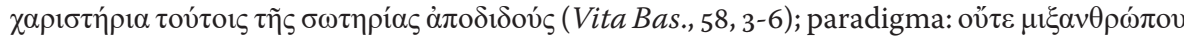

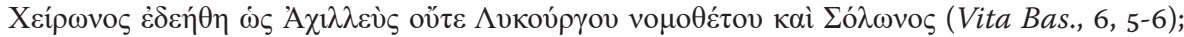

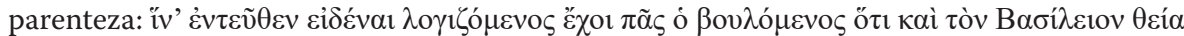

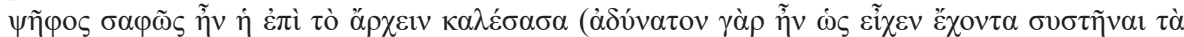

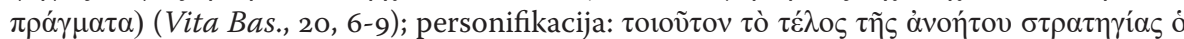

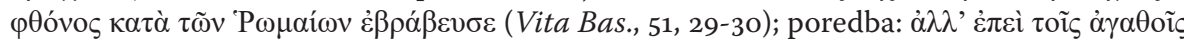

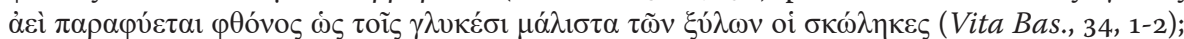

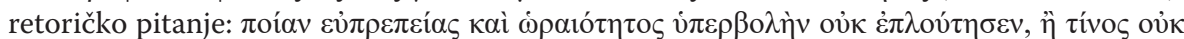

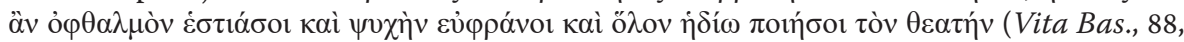
10-13).

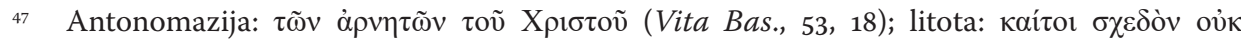

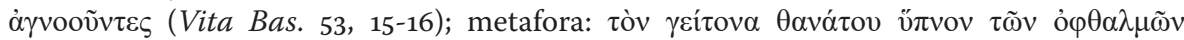

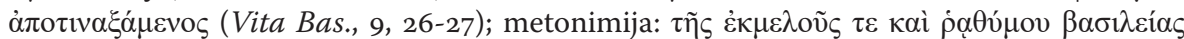

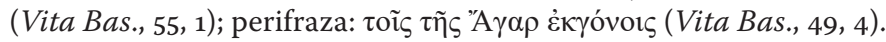


leksikom, prenoseći pritom idejnu tematiku svoga izvora. ${ }^{48}$ Velika učestalost citiranja i parafraziranja očekivana je s obzirom na uzvišeni stil $\mathrm{u}$ kojem je ovaj pohvalni govor napisan, pri čemu treba naglasiti kako u ovome slučaju citati i parafraze stoje primarno u funkciji ornatusa, za razliku od De them., De adm. imp. i De cerim., gdje su oni informativna karaktera i iz kojih je autor crpio vijesti potrebne za građu svojih spisa. Postizanju uzvišena stilskog naboja u Bazilijevoj biografiji doprinose i brojne leksičko-frazeološke paralele s klasičnim grčkim autorima, Svetim pismom i bizantskim grčkim piscima; u njima se ne citira ili prerađuje tuđa misao, već je tu riječ o sintagmama preuzetima iz drugih izvora koje su uklopljene u rečeničnu strukturu. ${ }^{49}$

Najbliži Vita Bas. po jezičnim je osobitostima, kako je već zamijetio Moravcsik, govor De imag. Edessena. Ševčenko (1992: 185, bilj. 46) je izdvojio oko dvadeset i pet zajedničkih leksičko-frazeoloških paralela u obama djelima, na temelju čega je zaključio kako je njihov autor isti. ${ }^{50}$ Ovomu ćemo pridodati i to da oba djela pokazuju najveće sličnosti i u stilističkome aspektu; osim što su pisana visokim stilom i što im je jezik izvještačen, a rečenice duge i kompleksne, u obama je upotrijebljen najveći broj ukrasnih stilskih sredstava. Među uočenim stilskim figurama u De imag. Edessena s Vita Bas. se u najvećem broju podudaraju figure iskaza (adjunkcija, anafora, asindeton, etimološka figura, hiperbat, homeoarkt, homeoteleut, izokolon s homeoptotom ili homeoteleutom, metabola, paromeoza, paronomazija, poliptot, polisindeton, sinonimija, tradukcija, zeugma).. ${ }^{51}$ Što se tiče figura mišljenja, javlja se njihov

48 Usp. apparatus fontium i index locorum u Ševčenkovu izdanju Vita Bas., te Serreqi Jurić, 2016: 250-271.

49 Kao primjer uporabe leksičko-frazeoloških paralela navodimo npr. Vita Bas., 6o, 3-4:

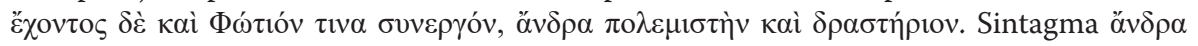

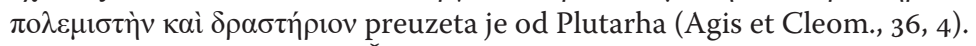

5o Popis takvih mjesta vidi u Ševčenko, 1992: 185, bilj. 46. Usp. i apparatus fontium i index locorum u Ševčenkovu izdanju Vita Bas.

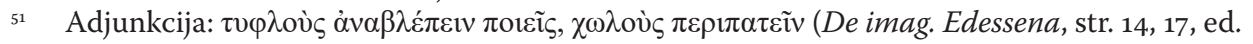

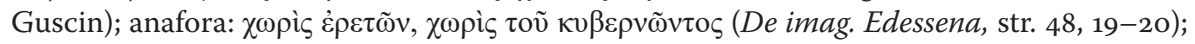

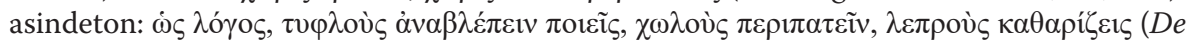
imag. Edessena, str. 14, 16-17); etimološka figura: oṽ $\theta \varepsilon o \varepsilon ı \delta o \tilde{\varsigma ~ \varepsilon ̇ \kappa \varepsilon i ́ v o v ~ \varepsilon i ́ \delta o v \varsigma ~ \varepsilon ̇ \kappa \tau v ́ \pi \omega \sigma ı v ~(D e ~}$

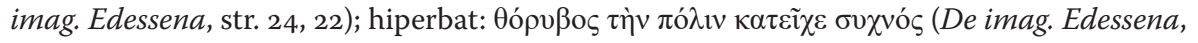

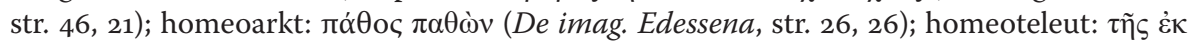




\section{dosta manji broj u odnosu na Bazilijevu biografiju (antiteza, epanorto- za, epifonem, hijazam, hipotipoza, obsekracija, parenteza, paradigma, poredba), ${ }^{52}$ a od tropa zastupljene su antonomazija, litota, metafora i}

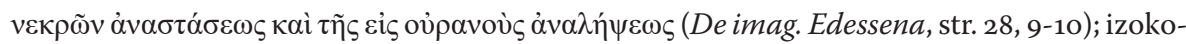

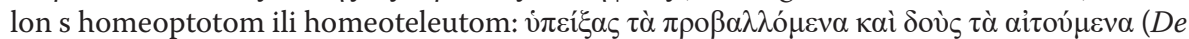

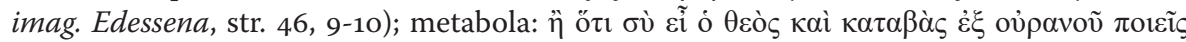

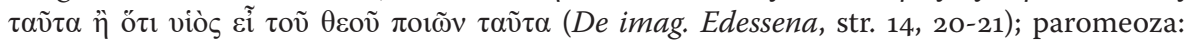

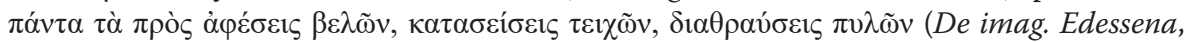

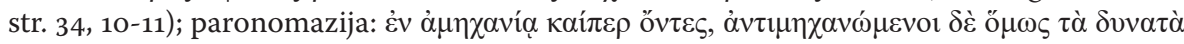

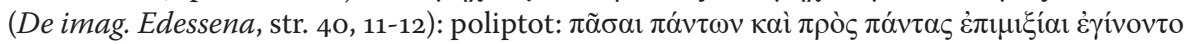

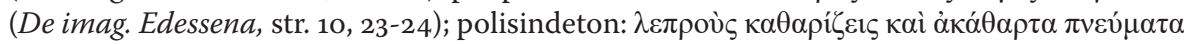

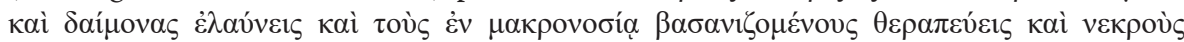

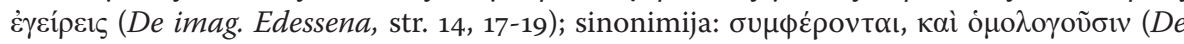

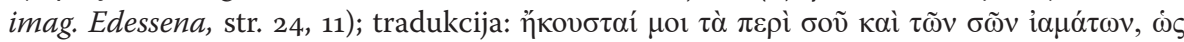
őv

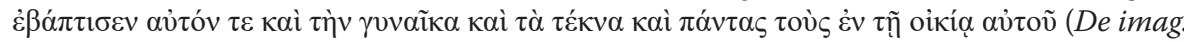
Edessena, str. 30, 13-14).

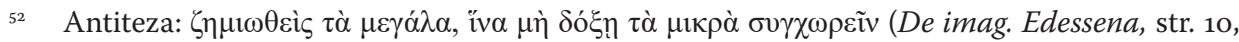

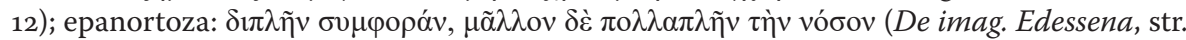

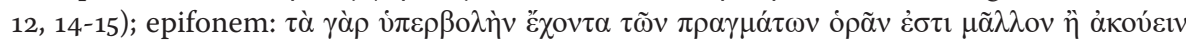

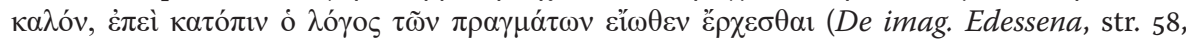

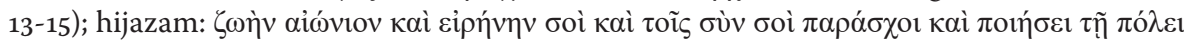

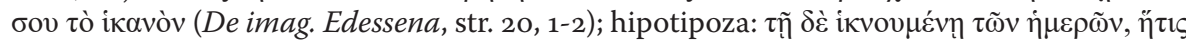

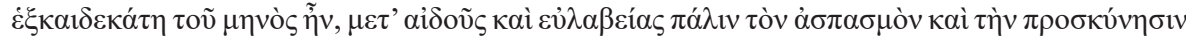

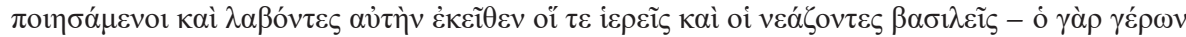

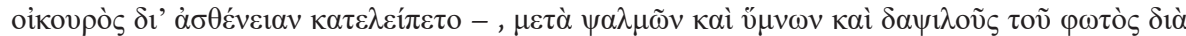

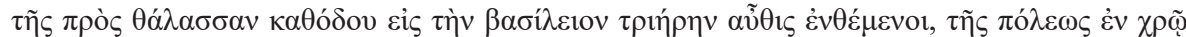

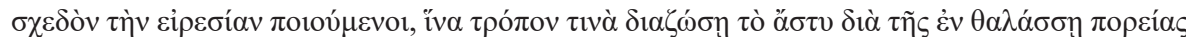

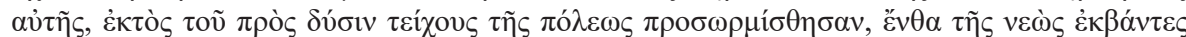

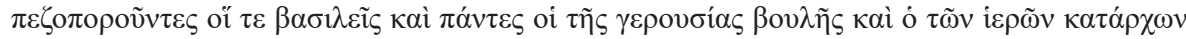

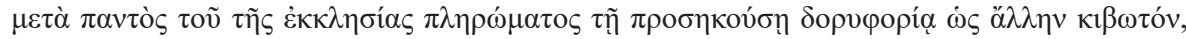

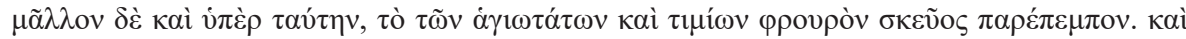

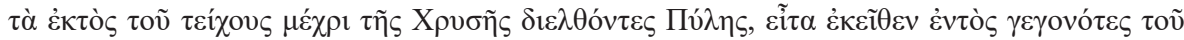

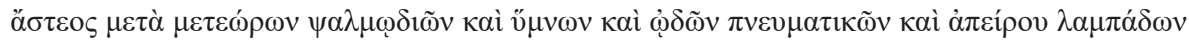

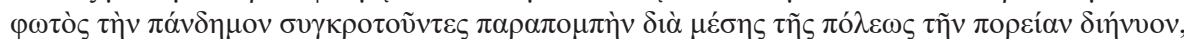

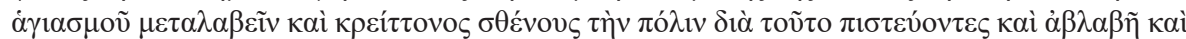

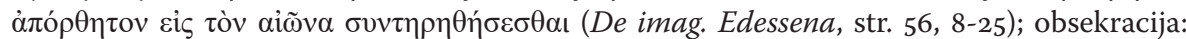

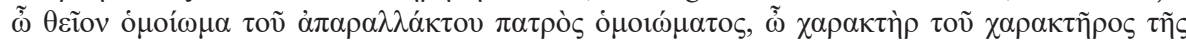

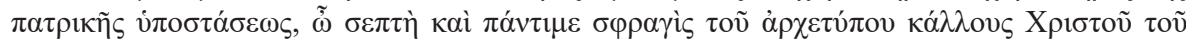

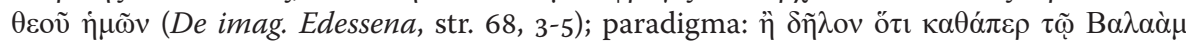

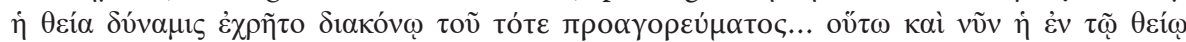

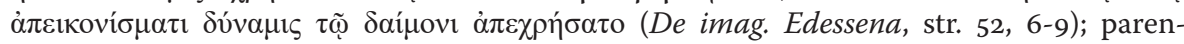

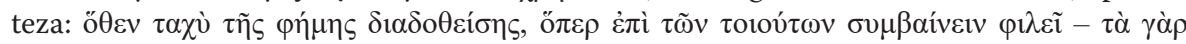

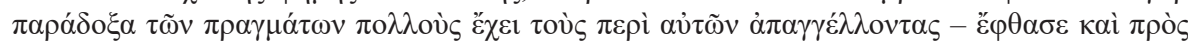

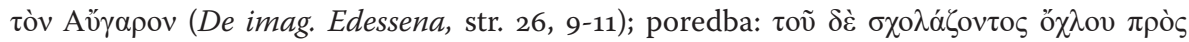


perifraza..$^{53}$ Također, i ovdje su uklopljeni citati, parafraze i leksičko-frazeološke paralele iz Svetoga pisma, što ne začuđuje s obzirom na tematiku djela, no ipak u vidno manjoj mjeri nego u Bazilijevoj biografiji. ${ }^{54}$

Ono što je svakako znakovito i što bi, pored leksičko-frazeoloških paralela, također moglo upućivati na istoga autora jest to da se u obama djelima susreće uporaba kombinacije hijazma i hiperbata. Naime, monotoniju koja bi se stvorila učestalom pojavom hijazama autor Vita Bas. vješto razbija na taj način da nerijetko hijazam isprepliće s hiperbatom. ${ }^{55}$ Takav spoj tih dviju stilskih figura uočen je na nekoliko mjesta u $D e$ imag. Edessena, u Porfirogenetovim pismima i u vojnim govorima, dok se u ostalim razmatranim dijelovima carevih spisa gotovo nigdje više ne pojavljuje. ${ }^{56}$

\subsection{Vojni govori}

Kako bismo upotpunili sliku o stilskim razinama u Porfirogenetovim djelima, preostaje nam još razmotriti dva careva svečana vojna govora. Iako je poznato kako Porfirogenet nije sudjelovao ni u jednome vojnom pohodu (Ahrweiler, 1967: 394; Ševčenko, 1992: 178, bilj. 23), govori upućeni bizantskoj vojsci održani su krajem careve vladavine. Prvi, koji nema adresata, datira se oko 952. - 953. godine, a drugi, adresiran

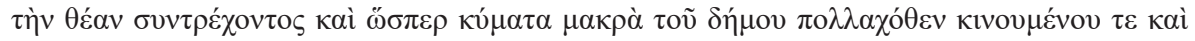

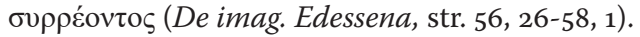

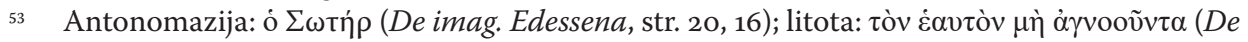

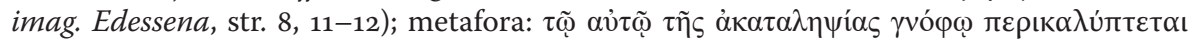

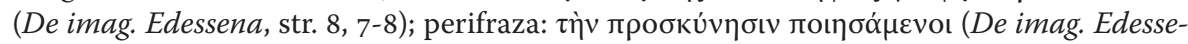
na, str. 56, 9-10).

${ }_{54}$ Usp. apparatus fontium u izdanju E. von Dobschütz (1899: $\left.38^{* *{ }^{*}}-85^{* * *}\right)$.

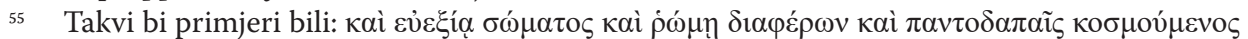

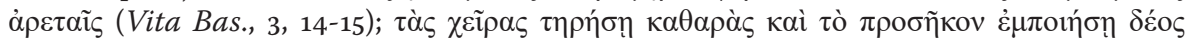
(Vita Bas., 62, 21-22). Radi izbjegavanja monotonije autor Vita Bas. često kombinira i izoko-

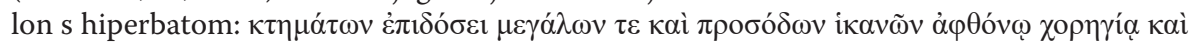

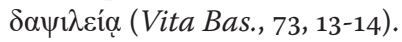

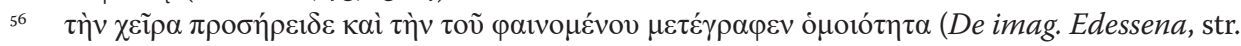

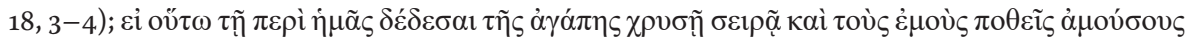

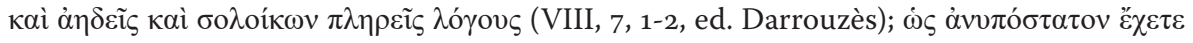

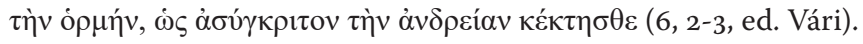


istočnim stratezima, oko 958. (Ahrweiler, 1967: 402).57 Govori pokazuju stilske karakteristike veoma slične onima koje su uočene u carevim pismima te $\mathrm{u}$ analiziranim dijelovima $D e a d m$. imp. Njihov je autor $\mathrm{u}$ najvećoj mjeri upotrijebio figure iskaza (adjunkcija, anafora, asindeton, hiperbat, homeoarkt, homeoteleut, izokolon s homeoptotom ili homeoteleutom, metabola, paromeoza, paronomazija, poliptot, polisindeton, prosapodoza, sinonimija, zeugma); ${ }^{8}$ kao što je očekivano, manje su brojne figure mišljenja (antapodoza, antiteza, epanortoza, hijazam, paradigma, personifikacija, poredba), ${ }^{59}$ a najrjeđi tropi (antonomazija,

57 Izdanje prvoga govora priredila je H. Ahrweiler (1967), a drugoga R. Vári (1908).

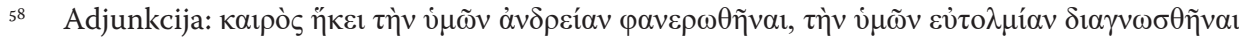

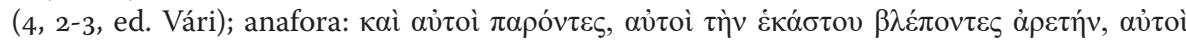

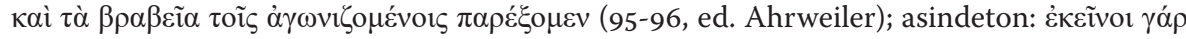

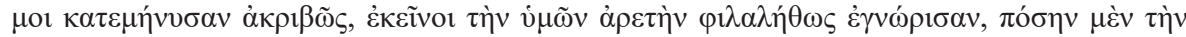

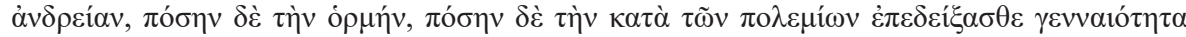

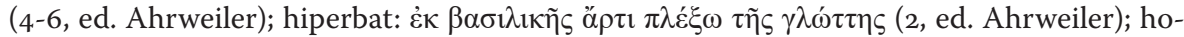

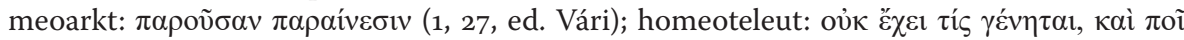

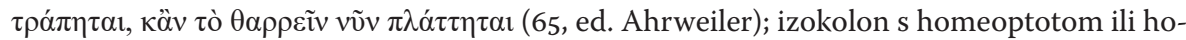

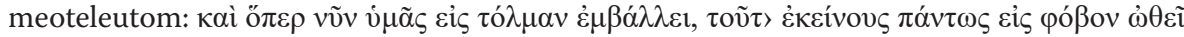

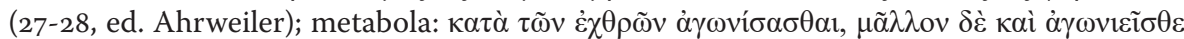

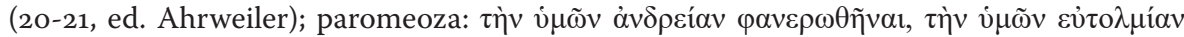

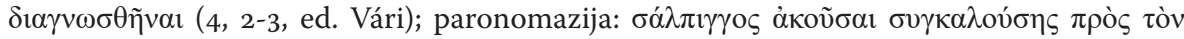

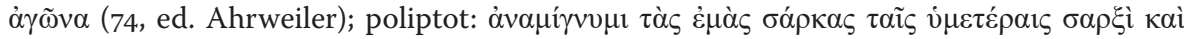

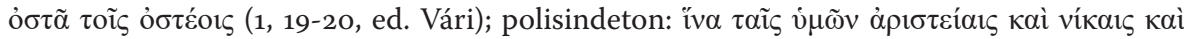

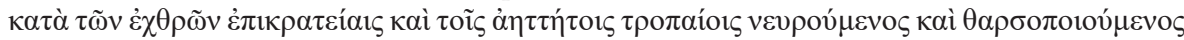

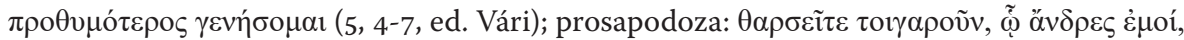

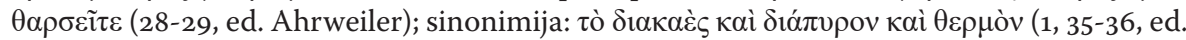

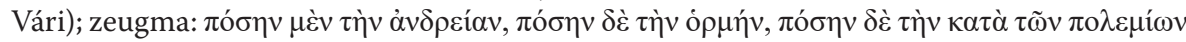
$\dot{\varepsilon} \pi \varepsilon \delta \varepsilon \dot{\xi} \xi \alpha \sigma \theta \varepsilon \gamma \varepsilon v v \alpha$ ió $\tau \tau \alpha$ (5-6, ed. Ahrweiler).

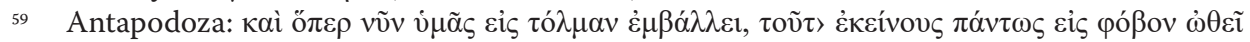

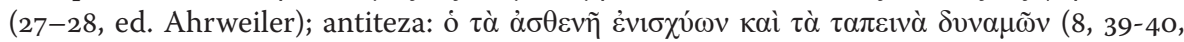

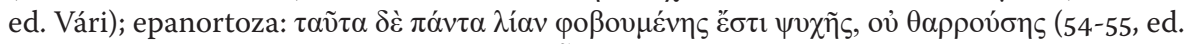

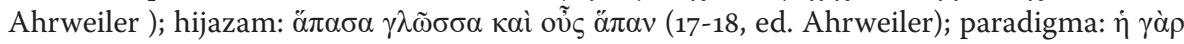

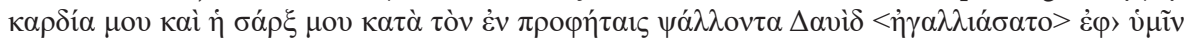

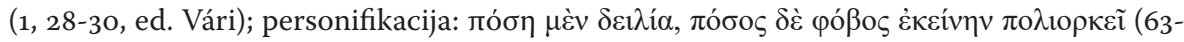

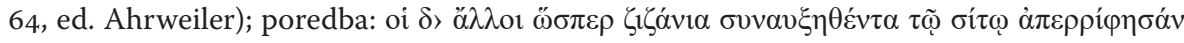
$\tau \varepsilon \kappa \alpha i ̀ ~ \alpha ̇ \pi \varepsilon \beta о ч \kappa о \lambda \eta ́ \theta \eta \sigma \alpha(4,16-18$, ed. Vári). 
metafora, perifraza). ${ }^{60} \mathrm{I} \mathrm{u} \mathrm{ovome} \mathrm{je} \mathrm{slučaju} \mathrm{autor} \mathrm{na} \mathrm{nekoliko} \mathrm{mjesta} \mathrm{po-}$ segnuo za citatima i parafrazama iz Svetoga pisma. ${ }^{61}$

\section{Zaključak}

Stilska obilježja odabranih dijelova Konstantinova literarnog opusa $\mathrm{s}$ velikom nam sigurnošću potvrđuju kako je car pisao u šest različitih stilskih razina. Njihov bi poredak od najviše stilske razine ka najnižoj izgledao ovako: ${ }^{62}$

1) Vita Bas. ${ }^{63}$

2) De imag. Edessena ${ }^{64}$

3) korespondencija s Teodorom iz Kizika ${ }^{65}$

4) svečani vojni govori ${ }^{66}$

5) dijelovi De adm. imp. (uvodno poglavlje, pogl. 1, 4-24 te pogl. 13, $12-200)^{67}$

6) uvodno poglavlje De them. i De cerim. te dijelovi De expeditione $e^{68}$

Konstantinova se višestruka književna uloga zrcali u tome što se među spisima, koji su do nas došli pod carevim imenom, njeguje nekoliko vrsta književnih žanrova, od carskoga govora (Vita Bas.), ostalih vrsta govora (De imag. Edessena, vojni govori), diplomatsko-dokumentarnih spisa (De adm. imp., De cerim.), sve do zemljopisno-administrativnih (De them.) i vojnih priručnika (De expeditione). Imamo li u vidu

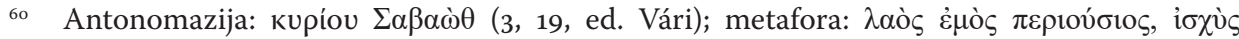

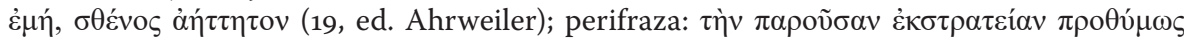
$\pi$ oiń $\sigma \alpha \tau \varepsilon(8,2-3$, ed. Vári).

${ }_{61}$ Usp. Ahrweiler, 1967: 398, bilj. 14, 15 i 16.

62 Pri sastavljanju poretka, osim vrsta stilskih figura i tropa, u obzir je uzeta i učestalost njihove pojave u razmatranim dijelovima Porfirogenetovih spisa.

${ }_{63}$ Četrdeset i tri stilske figure (dvadeset figura iskaza, osamnaest mišljenja i pet tropa).

64 Dvadeset i devet stilskih figura (šesnaest figura iskaza, devet mišljenja i četiri tropa).

${ }_{65}$ Dvadeset i četiri stilske figure (trinaest figura iskaza, devet mišljenja i dva tropa).

66 Dvadeset i pet stilskih figura (petnaest figura iskaza, sedam mišljenja i tri tropa).

${ }_{67}$ Dvadeset i jedna stilska figura (dvanaest figura iskaza, šest mišljenja i tri tropa).

${ }_{68}$ U prologu De them. uočeno je sedam figura iskaza, u uvodnome poglavlju De cerim. devet figura iskaza i jedna mišljenja (ukupno deset), a u analiziranim dijelovima De expeditione sedam figura iskaza, tri mišljenja te dva tropa (ukupno dvanaest). 
takvu heterogenost književnih vrsta, pojava različitih stilskih razina u tome slučaju nije neobična. Svjesnost o različitim stilskim izričajima u svojim djelima potvrđuje nam i sam Konstantin na dvama mjestima, $\mathrm{u}$ prvome poglavlju De adm. imp. te u prologu De cerim., gdje je car iznio vlastita očitovanja o jeziku i stilu svojih djela:

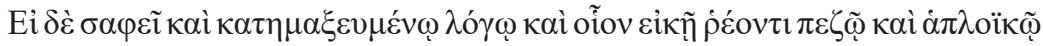

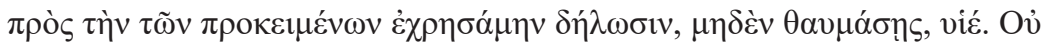

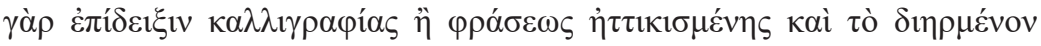

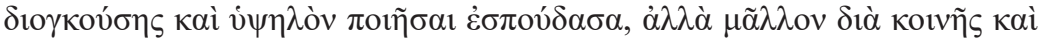

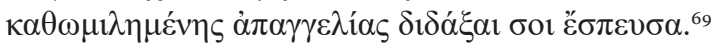

„Ako sam se za izlaganje predmeta poslužio utabanom stazom jasnoga govora i takoreći osrednjim i jednostavnim izričajem, ne čudi se, sine. Jer nisam se trudio pokazati primjer lijepog pisanja niti nadutog i uzvišenoga aticističkog stila, nego sam radije nastojao poučiti te svakodnevnim i govornim jezikom."

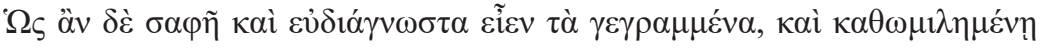

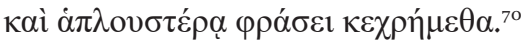

„Kako bi ono što je napisano bilo jasno i lako razumljivo, poslužili smo se govornim i jednostavnijim jezikom."

Porfirogenet kaže da je hotimice upotrijebio jednostavan i govorni jezik iz dvaju razloga, da bi ono što je napisano bilo lakše razumljivo i zato što želi poučiti svoga sina, a ne pružiti primjer pisanja visokim stilom. ${ }^{71}$ To nam ujedno daje i odgovor na pitanje zašto se on, kao isti pisac, u svojim djelima služi sad arhaizirajućim, sad govornim grčkim jezikom, što je neke proučavatelje carevih spisa nagnalo u sumnju je li moguće da isti autor piše tako različitim vrstama stilova.

Ohrabreni carevim riječima, kao i na temelju našega istraživanja, možemo zaključiti kako stilske razlike u Konstantinovim djelima stoje $\mathrm{u}$

69 De adm. imp., 1, 8-13.

70 De cerim., I, str. 2, 15-17.

${ }^{71}$ Zanimljivo je, kao što je primijetio Moravcsik (1939: 518), to da se car-pisac upravo u uvodnim poglavljima tih spisa te na mjestima koja su pisana u prvome licu (tu spadaju i ovi citirani dijelovi gdje se objašnjava upotreba jednostavnoga jezika), kao i ondje gdje se obraća sinu s opomenom ili poukom, poslužio arhaizirajućim grčkim jezikom, dok je jednostavan govorni jezik s vulgarizmima prisutan u ostalim dijelovima spisa koji se temelje na starijim izvorima. 
neodvojivoj vezi s njihovim različitim književnim vrstama, tematikom spisa te s time komu su djela bila adresirana odnosno koja je bila njihova namjena. Generički aspekt kao i sadržaj građe uvjetovali su stupanj autorove angažiranosti oko podizanja stilskoga naboja. Najuzvišeniji stilski izričaj nalazimo u spisima sastavljenima za široku publiku. Tu prvenstveno spada Vita Bas., pohvalni govor napisan u čast Porfirogenetova djeda Bazilija, čiji se političko-propagandni karakter potvrđuje time što je glorifikacija Bazilija i makedonske dinastije trebala polučiti oslobođenje Porfirogenetova djeda od krivnje za ubojstva dviju osoba hijerarhijski iznad njega, cezara Barde i cara Mihaela III., zahvaljujući kojima je neminovno bio ubrzan Bazilijev dolazak na vlast. Široj je javnosti bio namijenjen i govor De imag. Edessena, kojim je obilježen povratak čudotvorne Kristove slike iz Edese u Konstantinopol 944. godine, što je za religiozne Bizantince zacijelo bio važan događaj. Nešto nižu razinu stilskoga izričaja nalazimo u pismima koja je Konstantin razmijenio s Teodorom, biskupom grada Kizika, te u vojnim govorima upućenima bizantskoj vojsci krajem Porfirogenetove vladavine. Unatoč tomu što je stupanj uporabe stilskih sredstava ovdje manji nego u Vita Bas. i De imag. Edessena, ipak je zamjetan autorov trud usmjeren postizanju specifična estetskog učinka. Intiman i prijateljski karakter korespondencije s Teodorom, Porfirogenetovim bliskim prijateljem i vrlo učenim čovjekom, potaknuo je cara na dinamiziranje uporabe retoričkih ukrasa, a isti je slučaj i kod vojnih govora čija je adhortativna funkcija trebala osnažiti moral i duh bizantske vojske u vrijeme kada je Bizant vodio ratove sa Sajfom al-Daulom, pripadnikom arapske dinastije Hamdanida. Carevim pismima i vojnim govorima po svojim se stilskim obilježjima približavaju razmatrani dijelovi De adm. imp., spisa diplomatskoga karaktera s povjerljivim informacijama o tome kako upravljati bizantskim carstvom, koji je u svojoj glavnini pisan vrlo jednostavnim stilom (osobito oni dijelovi koji se temelje na starijim izvorima). Međutim, stilskom se izražajnošću izdižu ona mjesta gdje Konstantin piše u prvome licu ili se obraća sinu Romanu savjetima, poukama ili opomenama u toplu i didaktičnu tonu, koji proizlazi iz očeve brige i nastojanja da svoga sina opskrbi znanjem potrebnim za obavljanje dužnosti bizantskoga vladara. 
Najnižu stilsku razinu uočavamo u De them. i De cerim., spisima diplomatsko-dokumentarna sadržaja, čija nam rukopisna tradicija također potvrđuje da nisu bili namijenjeni objavljivanju kao ni za širu javnost. I oni su, kao i veći dio De adm. imp., pisani jednostavnim jezikom, no njihovi su prolozi stilski ujednačeni s ostalim dijelovima. Specifična tematika tih spisa (opis tema koje su u sastavu Bizantskoga Carstva u De them. te opis bizantskoga dvorskog ceremonijala u De cerim.), kao i okolnost da se većina njihova sadržaja temelji na građi preuzetoj iz drugih izvora, onemogućila je njihovu autoru da stilski intervenira u većoj mjeri. Niska razina stilskoga izričaja u vojnome priručniku De expeditione, koji razrađuje detalje potrebne za organizaciju careva vojnog pohoda, također je uvjetovana tematikom kao i time što njegova glavnina počiva na starijem vrelu.

Podatak da se u razmotrenim dijelovima careva književnog korpusa ponavlja veći broj određenih stilskih figura i tropa (od figura iskaza adjunkcija, anafora, hiperbat, homeoarkt, homeoteleut, izokolon, metabola, paromeoza, paronomazija, poliptot, polisindeton, sinonimija i zeugma, od figura mišljenja antiteza, epanortoza, hijazam i poredba te od tropa antonomazija, perifraza i metafora) nedvojbeno potvrđuje postojanje zajedničkih stilskih karakteristika među tim djelima. Pored toga, sklonost učestalomu posezanju za biblijskim citatima i parafrazama (Vita Bas., De imag. Edessena, korespodencija s Teodorom, vojni govori, dijelovi De adm. imp.), kao i kombiniranje hijazma s hiperbatom (Vita Bas., De imag. Edessena, korespodencija s Teodorom, vojni govori), također ukazuju na specifičan autorov stilski afinitet i mogli bi ići u prilog tomu da je autor tih djela isti te da su u ovome slučaju stilske varijacije uvjetovane zahtjevima koje je redaktoru spisa nametala tematika odnosno sadržaj građe, ali i to jesu li spisi bili namijenjeni široj publici ili su zbog svoga povjerljivog i dokumentarnog karaktera morali ostati unutar carskoga dvorskog arhiva. 


\section{Izvori}

- Ahrweiler, Hélène (1967) „Un discours inédit de Constantin VII Porphyrogénète“, Travaux et Mémoires, god. II, str. 393-404.

- Bekker, Immanuel (ur.) (1838) Theophanes Continuatus, Impensis Ed. Weberi, Bonnae.

- Darrouzès, JeAn (ed.) (1960) Épistoliers byzantins du Xe siècle, Institut français d'Études byzantines, Paris.

- Darrouzès, Jean - Leendert G. Westerink (ur.) (1978) Théodore Daphnopatès. Correspondance, Éditions du Centre National de la Recherche Scientifique, Paris.

- Guscin, MARK (ur.) (2009) The Image of Edessa, Brill, Leiden Boston.

- Haldon, John F. (ur.) (1990) Constantine Porphyrogenitus. Three treatises on Imperial Military Expeditions, Verlag der Österreichischen Akademie der Wissenschaften, Wien.

- Moravcsik, Gyula - Romilly J. H. Jenkins (ur.) (1967) Constantine Porphyrogenitus. De administrando imperio, 2. izd., Dumbarton Oaks, Center for Byzantine Studies, Washington.

- Pertusi, Andrea (ur.) (1952) Costantino Porfirogenito. De thematibus, Biblioteca Apostolica Vaticana, Città del Vaticano.

- ŠEvČenko, IHOR (ur.) (2011) Chronographiae quae Theophanis Continuati nomine fertur liber quo vita Basilii imperatoris amplectitur, De Gruyter, Berlin - Boston.

- VÁRI, Rudolf (1908) „Zum historischen Exzerptenwerke des Konstantinos Porphyrogennetos“, Byzantinische Zeitschrift, god. XVII, br. 1, str. 75-85.

- Vogt, Albert (ur.) (1967) Constantin VII Porphyrogénète. Le Livre des Cérémonies, sv. I-II, 2. izdanje, Les Belles Lettres, Paris.

- Von Dobschütz, ERnst (1899) Christusbilder: Untersuchungen zur christlichen Legende, J. C. Hinrichs'sche Buchhandlung, Leipzig. 


\section{Literatura}

- Ahrweiler, Hélène (1981) „Sur la date du De Thematibus de Constantin VII Porphyrogénète", Travaux et Mémoires, god. VIII, str. 1-5.

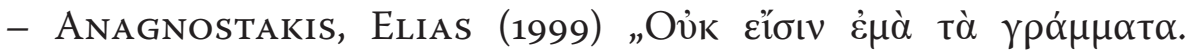

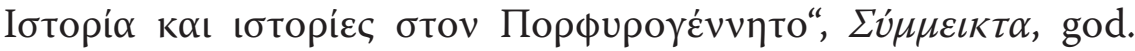
XIII, str. 97-139.

- Bury, John B. (1907) „The Ceremonial Book of Constantine Porphyrogenitus“, The English Historical Review, god. XXII, br. 86, str. 209-227 i 417-439.

- BURY, John B. (1908) „Rasprava De administrando imperio“, Vjestnik Kraljevskog hrvatsko-slavonsko-dalmatinskog arkiva, god. X, str. 91-144. (hrvatski prijevod izvornika pod naslovom BURY, JOHN B. (1906) „The treatise De administrando imperio“, Byzantinische Zeitschrift, god. XV, br. 2, str. 517-577.)

- Hirsch, Ferdinand (1876) Byzantinische Studien, Verlag von S. Hirzel, Leipzig.

- Hunger, Herbert (1978) Die hochsprachliche profane Literatur der Byzantiner, sv. I-II, C. H. Beck'sche Verlagsbuchhandlung, München.

- Katičić, Radoslav (1977) „Bizantska književnost“, VRatović, Vladimir (ur.) Povijest svjetske književnosti, sv. II, Mladost, Zagreb, str. 332-333.

- Krumbacher, Karl (1897) Geschichte der Byzantinischen Litteratur von Justinian bis zum Ende des Oströmischen Reiches (5271453), 2. izd., C. H. Beck'sche Verlagsbuchhandlung, München.

- Lemerle, Paul (1986) Byzantine Humanism. The First Phase. Notes and remarks on education and culture in Byzantium from its origins to the 1oth century, Australian Association for Byzantine Studies, Byzantina Australiensia 3, Canberra. (engleski prijevod izvornika pod naslovom LEMERLE, PAUL (1971) Le premier humanisme byzantin. Notes et remarques sur enseignement et culture à 
Byzance des origines au Xe siècle, Presses Universitaires de France, Paris.)

- LonČAr, Milenko (2002a) „Filološka analiza Porfirogenetovih vijesti o Hrvatima", doktorska disertacija, Filozofski fakultet u Zadru Sveučilišta u Splitu, Zadar.

- LonČar, Milenko (2002b) „Dalmatinske etimologije Konstantina Porfirogeneta", Folia onomastica Croatica, god. XI, str. 149-174.

- Mommsen, Tycho (1895) Beiträge zu der Lehre von den griechischen Präpositionen, 2. izd., Weidmannsche Buchhandlung, Berlin.

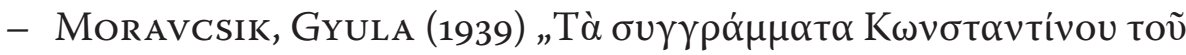

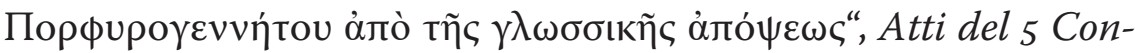
gresso Internazionale di Studi Bizantini, Roma 20.-26. settembre 1936., Tipografia del Senato del dott. G. Bardi, Roma, str. 514-520.

- Moravcsik, Gyula (1983) Byzantinoturcica, sv. I, 3. izd., Brill, Leiden.

- Ostrogorsky, Georg (1953) „Sur la date de la composition du Livre des Thèmes et sur l'époque de la constitution des premiers thèmes d'Asie Mineure“, Byzantion, god. XIII, str. 31-66.

- Rambaud, Alfred (1870) L'Empire grec au Xe siècle. Constantin Porphyrogénnète, Librairie A. Franck, Paris.

- Serreqi Jurić, Teuta (2016) „Usporedba jezično-stilskih osobitosti Porfirogenetovih djela Vita Basilii i De thematibus", doktorska disertacija, Filozofski fakultet Sveučilišta u Zagrebu, Zagreb.

- Signes Codoñer, JuAn (1989) „Algunas consideraciones sobre la autoría del Theophanes Continuatus", Erytheia, god. X, br. 1, str. 17-28.

- ŠEvČENKo, IHOR (1978) „Storia Letteraria“, La civiltà bizantina dal IX all'XI secolo: aspetti e problemi, Universita degli Studi di Bari, Centro di Studi Bizantini, Bari, str. 91-127.

- ŠEvČenko, Ihor (1992) „Re-reading Constantine Porphyrogenitus“, Byzantine Diplomacy: Papers from the Twenty-fourth Spring Symposium of Byzantine Studies, Cambridge, March 1990, 
Shepard, Jonathan - Franklin, Simon (ur.), Variorum, Aldershot, str. 167-195.

- Tartaglia, Luigi (1982) „Livelli stilistici in Costantino Porfirogenito“, Jahrbuch der Österreichischen Byzantinistik, god. XXXII, br. 3, str. 197-206.

- Toynbee, Arnold (1973) Constantine Porphyrogenitus and his World, Oxford University Press, London.

- Varona, Patricia (2010) „Contribución al problema de la cronología y las fuentes de la Vita Basilii“, Byzantinische Zeitschrift, god. 102, br. 2, str. 739-775. 
Original scientific paper

Received November 21, 2017.

Teuta Serreqi Jurić

University of Zadar, Department of Classical Philology

\section{STYLE LEVELS IN THE WORKS BY CONSTANTINE PORPHYROGENITUS}

\section{Abstract}

The question of the authorship of the literary corpus preserved under the name of Byzantine Emperor Constantine VII. Porphyrogenitus (913959) has preoccupied scholars for more than a century. Uncertainty in the emperor's authorship arose for the most part due to the multitude of style levels of his writings, which in recent research has resulted in a disputation of the authorship of Porphyrogenitus involving most of the works attributed to him. This paper deals with the stylistic features of those parts of the Corpus Constantineum in which, according to experts, Porphyrogenitus had his own creative share. The results show that Constantine wrote using approximately six different style levels, and that the appearance of different stylistic expressions was conditioned by the literary genre, the subject matter and the circumstances addressed by the work in question. The common stylistic features present in the segments of the emperor's writings covered in this paper point to the fact that, in this case, it is possible that they were written by the same author, one who varied his writing style.

Keywords: Constantine VII Porphyrogenitus; figures of speech; style levels; authorship 